\title{
Geology and metallogenic potential of the northwesternmost Norrbotten Province around Altevatn in Troms, northern Norway
}

\author{
Trond Slagstad' ${ }^{1}$ Biørn Willemoes-Wissing ${ }^{1}$, Nolwenn Coint ${ }^{1}$, Alexandros Stampolidis', \\ Morgan Ganerød' \& Frode Ofstad'
}

${ }^{1}$ Geological Survey of Norway, P.O. Box 6315 Sluppen, 7491 Trondheim, Norway.

E-mail corresponding author (Trond Slagstad): trond.slagstad@ngu.no

\begin{abstract}
The Altevatn area constitutes the northwesternmost part of the Archaean to Palaeoproterozoic Norrbotten Province in north-central Scandinavia, making it strategically located with respect to correlations between Fennoscandia proper and apparently similar units to the west, outboard of the Caledonian nappes. Low-grade, c. $1.9 \mathrm{Ga}$, supracrustal rocks in the Norrbotten Province in Sweden host numerous economical mineralisations, including the world-class Kirunavaara apatite iron deposit. However, the relative inaccessibility of the Altevatn area has rendered it virtually unmapped, and thus leaving open the possibility of similar mineralisations on the Norwegian side. Bedrock and geophysical mapping and geochronological investigations, presented here, show that the Altevatn area consists of Neoarchaean migmatitic ortho- and paragneisses, intruded by c. $1.8 \mathrm{Ga}$ granitoids, ranging in composition from gabbro and monzonite to granite. No rocks similar to the $c .1 .9$ Ga supracrustal rocks in the Norrbotten Province have been identified, suggesting that such mineralisations are unlikely to be found in the Altevatn area. However, a poorly exposed, high-magnetic gabbro shows relatively high concentrations of $\mathrm{Fe}, \mathrm{P}$, Ti and $\mathrm{V}$, providing the most interesting target for follow-up prospecting. Although structural evidence may be interpreted to reflect Svecofennian deformation, we have not found clear geochronological evidence of the Late Palaeoproterozoic accretionary processes that characterise much of Fennoscandia.
\end{abstract}

Keywords: Altevatn, Norrbotten Province, metallogeny, Fennoscandian Shield, Svecofennian, migmatite

Electronic Supplement 1: Geochronological data.

Received 11. November 2015 / Accepted 12. June 2016 / Published online 1. August 2016

\section{Introduction}

The MINN programme (Mineral Resources in North Norway) at the Geological Survey of Norway (NGU) was initiated in 2011. The main goal of the programme was to gather new geophysical and geological information and understanding from selected areas in northern Norway, and based on this newfound knowledge assess the potential for mineral resources in this part of the country.
The Altevatn area is located in eastern Troms, and represents the northwestern continuation of the Norrbotten Province in northern Sweden (Fig. 1). The Norrbotten Province is well known for its many mineral resources, of which the world-class Kirunavaara apatite iron deposit is the best known. The purpose of this paper is to present new field, petrographic, aeromagnetic and geochronological data from the Altevatn area, and compare the geological evolution of this hitherto poorly known area with that of the better-investigated

Slagstad, T., Willemoes-Wissing, B., Coint, N., Stampolidis, A., Ganerød, M. \& Ofstad, F. 2016: Geology and metallogenic potential of the northwesternmost Norrbotten Province around Altevatn in Troms, northern Norway. Norwegian Journal of Geology 95, 445-466. http://x.doi. org/10.17850/njg95-3-07. 


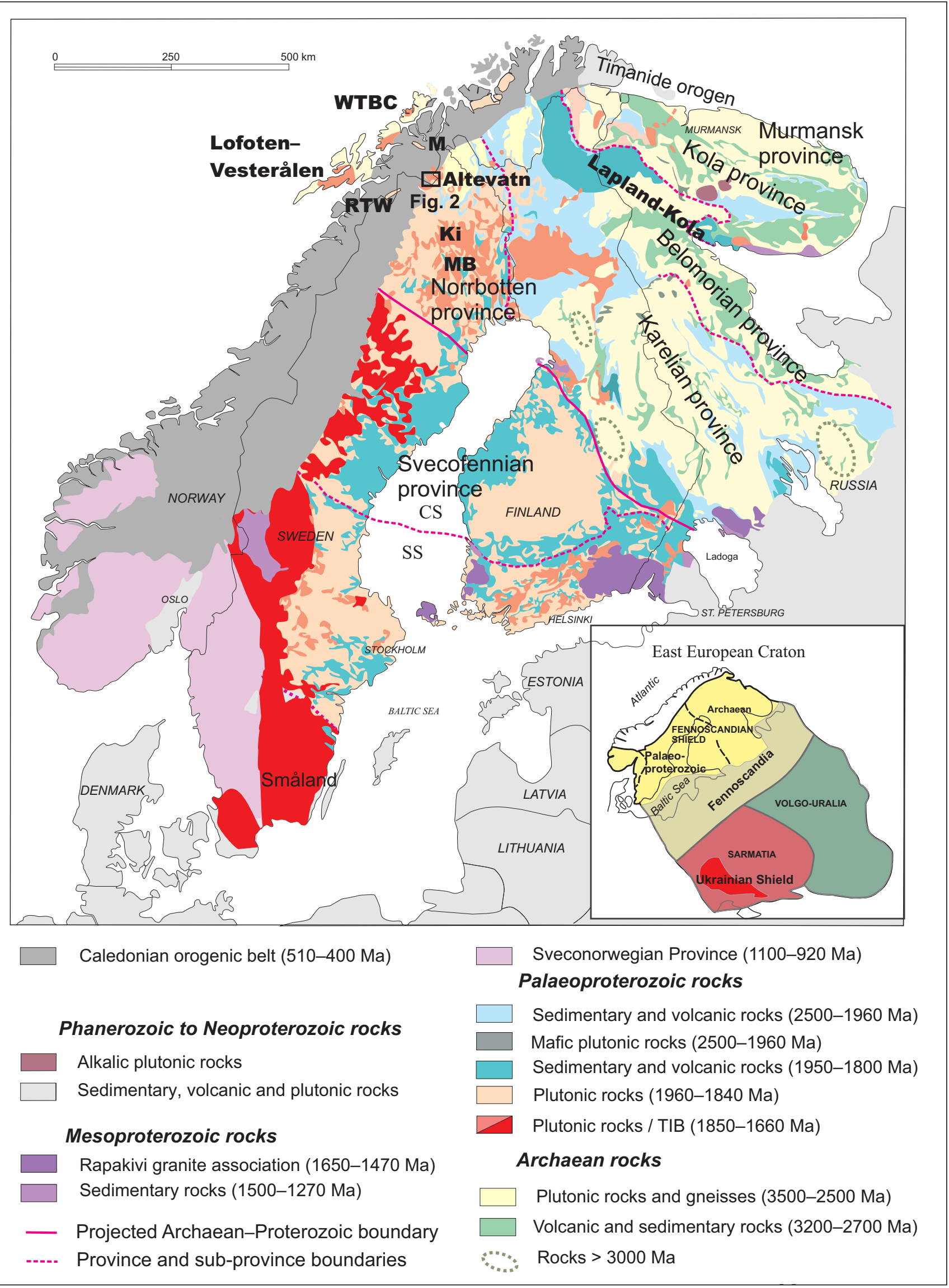

Figure 1. Fennoscandia and its location within the East European Craton. Simplified geological map based on Koistinen et al. (2001) and inset map based on Gorbatschev \& Bogdanova (1993). Subareas: CS - Central Svecofennia, SS - Southern Svecofennia. Areas and localities: Ki Kiruna, M - Mauken, MB - Malmberget, RTW - Rombak Tectonic Window, WTBC - West Troms Basement Complex. Modified from Lahtinen (2012). 
Norrbotten Province and other parts of Fennoscandia. Based on this new information, we assess the metallogenic potential of the Altevatn area and discuss the area's significance for understanding Svecofennian processes.

\section{Regional geology}

The Altevatn area is the northwesternmost, undisputed autochthonous part of the Fennoscandian Shield (Fig. 1). The continuation of the Shield to the northwest is concealed by overlying Palaeozoic Caledonian nappes, but apparently similar rocks have been described from areas along the Troms and Nordland coast, namely the Lofoten-Vesterålen area and West Troms Basement Complex (WTBC) (e.g., Myhre et al., 2013; Bergh et al., 2014), and to the southwest in the Rombak Tectonic Window (Korneliussen \& Sawyer, 1989; Angvik, 2014). As such, information from the Altevatn area can be used to strengthen or weaken correlations between the Fennoscandian Shield proper and these western outliers. Below, we present a brief introduction to the geology of these areas. The geology and metallogeny of the Norrbotten Province, of which the study area is a part, is described in more detail below.

The Fennoscandian Shield displays a general trend of decreasing age of geological activity towards the southwest (Fig. 1). The northeastern part of the Shield is dominated by Neoarchaean rocks, which give way southwestwards to the Palaeoproterozoic (2.0-1.8 Ga) Svecofennian Province. The early geological evolution is characterised by break-up of the Neoarchaean Kenorland supercontinent between 2.5 and $2.1 \mathrm{Ga}$ (e.g., Vogel et al., 1998; Daly et al., 2006), associated with widespread mafic and ultramafic magmatism, development of rift basins, high-grade metamorphism and extensional deformation, eventually resulting in ocean-floor spreading between $c$. 2.1 and $2.0 \mathrm{Ga}$ (Berthelsen \& Marker, 1986). Closure of these ocean basins resulted in arc-arc, arc-continent and continent-continent collisions between 1.95 and $1.87 \mathrm{Ga}$ (Berthelsen \& Marker, 1986; Daly et al., 2006). The term 'Svecofennian' has a variable usage, but generally refers to these accretionary and associated arc/back-arc processes resulting in reamalgamation of the various continental and arc fragments, forming the Fennoscandian Shield (see Roberts \& Slagstad, 2015 and references therein). The subsequent evolution of the SW margin of the Shield (the topic area of this study) is debated. Korja et al. (2006) suggested that active-margin processes ended in collision with Amazonia and/or an unknown continent to the west and south, respectively. However, the recognition that magmatism related to formation of the Transscandinavian Igenous Belt (TIB; Fig. 1) started as early as 1.86 $\mathrm{Ga}$ and was most likely related to the establishment of a continental magmatic arc (Högdahl et al., 2004), has led more recent workers to favour the establishment of an active continental margin following Svecofennian accretion (Lahtinen et al., 2009). This active margin appears to have remained active until c. $0.9 \mathrm{Ga}$ (Slagstad et al., 2013; Roberts \& Slagstad, 2015).

The northeastern Fennoscandian Shield is typically divided into five provinces, variably affected by Palaeoproterozoic processes (Hölta et al., 2008). These provinces include the Murmansk, Kola, Belomorian, Karelian and Norrbotten province (Fig. 1). Archaean rocks predominate in the northeast, and include tonalitetrondhjemite-granodiorite (TTG) suites, subordinate greenstone belts and paragneisses, yielding ages mainly between 2.9 and $2.7 \mathrm{Ga}$ (Hölta et al., 2008 and references therein). High-grade metamorphic events recorded in these rocks include 2.9-2.7 Ga, eclogite- or granulitefacies metamorphism, as well as younger, c. 1.9 Ga, highgrade metamorphic overprinting (Kaulina et al., 2010; Mints et al., 2010; Skublov et al., 2011), related to Fennoscandian reamalgamation.

The Lofoten-Vesterålen area and WTBC comprise 2.9-2.7 Ga TTG orthogneisses and greenstone belts, that underwent high-grade metamorphism and local migmatisation between c. 2.7 and 2.6 Ga (Corfu, 2007; Myhre et al., 2013). Palaeoproterozoic rifting and formation of rift basins, similar to that described from the Fennoscandian Shield above, is also documented from the WTBC, including the $2.40 \mathrm{Ga}$ Ringvassøya mafic dyke swarm (Kullerud et al., 2006b) and deposition of supracrustal rocks at 2.40-2.20 Ga (Vanna group; Bergh et al., 2007) and <2.0 Ga (Mjelde-Skorelvvatn and Torsnes belts; Myhre et al., 2011). The last magmatic event to affect the Lofoten-Vesterålen area and WTBC was emplacement of a voluminous AMCG (anorthosite-mangerite/monzonite-charnockite-granite) complex over a rather short time interval at around $1.80 \mathrm{Ga}$ (Corfu, 2004). An early stage of Neoarchean (c. $2.6 \mathrm{Ga}$ ) deformation formed an initially flat-lying, N-S-striking, gneissic foliation at highgrade metamorphic conditions, with local migmatisation (Bergh et al., 2010; Myhre et al., 2013). This Neoarchaean deformational event was followed by Svecofennian deformation, mainly related to NE-SW orthogonal crustal shortening, possibly related to arc accretionary events (Bergh et al., 2010), and orogen-parallel (i.e., NWSE-oriented) strike-slip shearing. A comparable structural evolution has been described from many of the other Svecofennian domains in Norway, including the Karasjok and Kautokeino greenstone belts and the Repparfjord Tectonic Window (Braathen \& Davidsen, 2000; Henderson et al., 2015; Torgersen et al., 2015). Although some of this Svecofennian deformation affects, and therefore postdates, c. 1.8 Ga magmatic rocks, part of the deformation is older. In contrast to the Neoarchaean high-grade events, the Svecofennian deformation took place at medium to low grade.

The Rombak Tectonic Window (RTW), southwest of the Altevatn area, consists mainly of lower amphibolite-facies 
metavolcanic rocks, metapelites, greywackes and minor amounts of impure carbonate and quartzite, intruded by voluminous, c. $1.8 \mathrm{Ga}$, granitoid batholiths (Korneliussen \& Sawyer, 1989; Angvik, 2014). The supracrustal rocks appear to have been deposited on a tonalitic basement (Gautelis Tonalite Complex), part of which has been dated at $1940 \pm 26 \mathrm{Ma}$ (Romer et al., 1992). Archaean rocks are sparse, but may be present as c. $2.7 \mathrm{Ga}$ tonalitic gneiss in Sjangeli, east in the RTW (Romer et al., 1992). Mineralisations in the RTW include: (i) synsedimentary $\mathrm{Pb}-\mathrm{Zn}$ and Fe-sulphide SEDEX deposits, (ii) synorogenic, intrusion-related, metasomatic, $\mathrm{As}-\mathrm{Au}-\mathrm{Cu}$ deposits, (iii) orogenic Au deposits along late Svecofennian shear zones, and (iv) late-orogenic $\mathrm{Cu}-\mathrm{Au}$ quartz veins (Angvik, 2014). These mineralisations are very different from the apatite iron and other types of mineralisation in the Norrbotten Province, described in more detail below, despite lithological and temporal similarities and interpreted tectonic setting. This difference could reflect formation in slightly different places within the same arc/back-arc system (Angvik, 2014), or reflect more local differences within the same volcanic system (A. Korneliussen, pers. comm., 2016). More work on the mineralisations and host rocks is needed to address this issue.

\section{Geology and metallogeny of the Norrbotten Province}

The geology and metallogeny of the Norrbotten Province was presented by Bergman et al. (2001) and Hallberg et al. (2012). Below, we present a summary based mainly on these works that provide a basis for our assessment of the metallogenic potential of the Altevatn area.

\section{Main geological units of the Norrbotten Province}

The Norrbotten Province of the Fennoscandian Shield is located on the border between Archaean and Proterozoic rocks to the northeast, and Proterozoic rocks to the southwest (Fig. 1). The most common Archaean rocks in the province are tonalitic, granodioritic and quartzdioritic orthogneisses that are commonly strongly deformed and metamorphosed at high grade. Only a handful of ages have been obtained from these rocks, yielding protolith ages around $2.7 \mathrm{Ga}$ (Welin et al., 1971; Skiöld, 1979; Skiöld \& Page, 1998; Martinsson et al., 1999). Supracrustal rocks of Archaean age include banded biotite gneisses of sedimentary origin, locally with garnet and sillimanite. Meta-arenitic gneisses, quartzites and metavolcanic rocks are found locally. The Archaean rocks have low magnetic susceptibilities and an average Q-value (Koenigsberger ratio) just below 0.4 (Bergman et al., 2001).

A range of Palaeoproterozoic rocks exist in the Norrbotten Province, and are typically subdivided into: (i) $c$.
2.44 Ga mafic to ultramafic intrusions, (ii) c. 2.40-1.96 Ga Karelian metasedimentary and mafic to intermediate metavolcanic rocks, and (iii) c. 1.96-1.85 Ga Svecofennian supracrustal rocks (Bergman et al., 2001). A fourth group comprises voluminous Svecofennian (c. 1.9-1.8 Ga) intrusive rocks. Most of the economic mineralisations in the Norrbotten Province are found within Karelian and Svecofennian supracrustal rocks, and the following review focuses on the Karelian Greenstone group and the Svecofennian Porphyrite and Porphyry groups. In addition, the generally barren Svecofennian intrusive rocks are presented because similar rocks abound in the Altevatn area (this work).

The Greenstone group comprises metabasalt, commonly graphite-bearing meta-argillite, crystalline carbonate rock, iron formations, chert and ultramafic rocks. Mafic dykes, some of which are interpreted to be coeval with the magmatism of the Greenstone group, are found in older Archaean and Karelian rocks.

The Porphyrite and Porphyry groups overlie the Greenstone group. The Porphyrite group is stratigraphically the lower of the two and consists of metamorphosed, plagioclase-phyric andesite and basalt, with minor intercalations of felsic tuffs and tuffites. Martinsson \& Perdahl (1995) suggested, based partly on the low $\mathrm{Ti}$ and $\mathrm{Zr}$ concentrations of the rocks, that the Porphyrite group is a calc-alkaline volcanic series formed in a compressional setting. An intermediate metavolcanic rock from the Porphyrite group yielded an age of $1880 \pm 3 \mathrm{Ma}$ (SGU unpublished result in Bergman et al., 2001).

The Porphyry group consists of high-Ti basalt, trachyandesite, microperthite-/albite-phyric rhyodacite to rhyolite, and locally volcaniclastic rocks. The stratigraphically lowest part of the group consists of metabasalt at least 4 $\mathrm{km}$ thick, whereas trachyandesite is mainly restricted to the footwall of the Kirunavaara iron ore, discussed below. The rocks of the Porphyry group are mildly alkaline, and Martinsson \& Perdahl (1995) suggested formation in an extensional environment. Radiometrically dated units include a $1882 \pm 24$ Ma metarhyolite near Kiruna (Welin, 1987), and two felsic metavolcanic rocks yielding identical ages of 1909+17/-16 (Skiöld \& Cliff, 1984).

The Archaean and Svecofennian rocks were intruded by voluminous Svecofennian plutonic rocks between c. 1.89 and $1.78 \mathrm{Ga}$ (Bergman et al., 2001 and references therein). The northwestern part of the Norrbotten Province, closest to the Altevatn area, is dominated by intrusive rocks of (i) the Perthite monzonite suite, (ii) the Granite-pegmatite association, and (iii) the Granitesyenitoid-gabbroid association.

The Perthite monzonite suite (Witschard, 1984) consists of monzonite and quartz monzonite, with syenitic compositions dominating over granitic types. The perthite granites are typically red and medium to coarse 
grained, and locally pyroxene bearing. The rocks of the Perthite monzonite suite are generally isotropic, but locally contain a magmatic foliation near pluton margins. Large intrusions of gabbro and diorite also belong to this suite of rocks, some of which have observable magmatic layering and several of which display a concentric, banded magnetic pattern (Bergman et al., 2001). Radiometric ages for the Perthite monzonite suite range from 1879 to $1858 \mathrm{Ma}$ (Skiöld \& Öhlander, 1989; SGU, unpublished analyses, plots presented in Witschard, 1996; Martinsson et al., 1999). The Perthite-monzonite suite contains ferromagnetic minerals which give it a strong remanent magnetisation and high magnetic susceptibility, with a mean Q-value of c. 0.5 (Bergman et al., 2001).

The Granite-pegmatite association (also referred to as Lina granite) consists of greyish red, weakly porphyritic and generally medium-grained granite, typically associated with pegmatite that in some areas forms large massifs. Mafic minerals are sparse and commonly restricted to biotite. Fragments of country rock are common, and dykes and veins of granite, pegmatite and aplite locally intrude the host rocks. One sample has yielded a U$\mathrm{Pb}$ zircon age of $1811 \pm 6 \mathrm{Ma}$ (SGU, unpublished data in Bergman et al., 2001). The rocks belonging to the Granite-pegmatite association are typically weakly foliated, and Bergman et al. (2001) suggested that they may have intruded while regional deformation was still active. Compared to most other rock units in the Norrbotten Province it has generally low magnetic susceptibilites and remanent magnetisations, with a Q-value below 0.25 (Bergman et al., 2001).

The Granite-syenitoid-gabbroid association consists of a large number of intrusions that have compositional similarities to the Transscandinavian Igneous Belt (TIB; Högdahl et al., 2004) in southern and central Sweden (Bergman et al., 2001). In the field, these rocks are very similar to those of the Perthite monzonite suite. Compositions vary from gabbro to granite, and syenite has been reported from southwest of Kiruna. Three ages have been published ranging from 1799 to 1792 Ma (Romer et al., 1994; SGU, unpublished data in Bergman et al., 2001). The rocks of this suite are characterised by high magnetic susceptibilities and a high natural remanent magnetisation, with a Q-value above 0.6.

The Vendian to Cambrian Dividal Group unconformably overlies the weathered Precambrian basement and was overthrust by nappes from the west during the Palaeozoic Caledonian orogeny. Kulling (1964) and Thelander (1982) described the Dividalen Group as consisting of quartzites, sandstones, siltstones with minor shaly intercalations, and black alum shales.

\section{Mineral occurrences in the Norrbotten Province}

The northern Norrbotten Province is dominated by different types of iron and copper deposits, whereas other metals, including zinc, lead, vanadium, titanium and cobalt, are found in only subeconomic concentrations. From an economic point of view, the apatite iron ores at Kiruna and Malmberget (Fig. 1) are the most important.

The metallic deposits are divided into (i) stratiformstratabound base metals and iron, (ii) apatite iron ores, (iii) epigenetic base metals, and (iv) other metals.

The ore minerals in the stratiform-stratabound deposits are either banded or laminated parallel to the bedding of their host rocks, or form massive lenses conformable to the wall rocks. This group also includes copper- or zinclead-dominated sulphide deposits, as well as banded iron formations and skarn-rich iron formations. All known occurrences of this group of deposits are hosted by the Greenstone group.

The apatite iron ores comprise magnetite-hematite deposits that are spatially related to the Porphyry group, and hosted either by this group or by the underlying Porphyrite group. The world-class Kirunavaare apatite iron deposit forms part of this group. This group of ores displays significant variation in host-rock relations, lithology and alterations, and has been subdivided into two distinct subgroups: a breccia type and a stratiformstratabound type. The breccia-type ores are found mainly in intermediate to mafic volcanic rocks in stratigraphically low positions in the Porphyry group or the underlying Porphyrite group. The stratiform-stratabound-type deposits form lenses in stratigraphically high positions within the Porphyry group, and are commonly associated with host-rock alteration, typically with sericite, biotite, tourmaline and carbonate.

In the epigenetic base metals group of deposits ore minerals are disseminated or occur in veinlets, veins and breccias. These deposits are found in the Greenstone group, as well as in the Porphyry and Porphyrite groups, where they are characterised by K-feldspar, scapolite, tourmaline and local sericite alterations.

Other metal deposits include a number of small orthomagmatic deposits, none of which are economically significant. A few titanium-vanadium-iron mineralisations have been found in mafic intrusions, and small amounts of nickel sulphides have been found in a few mafic to ultramafic intrusions. Disseminated molybdenite is found in some granitoids and pegmatites, and in the northern part of the Norrbotten Province, quartz veins related to the Granite-pegmatite association contain fluorite, molybdenite, pyrite and some scheelite where the granite intrudes Archaean gneiss. 


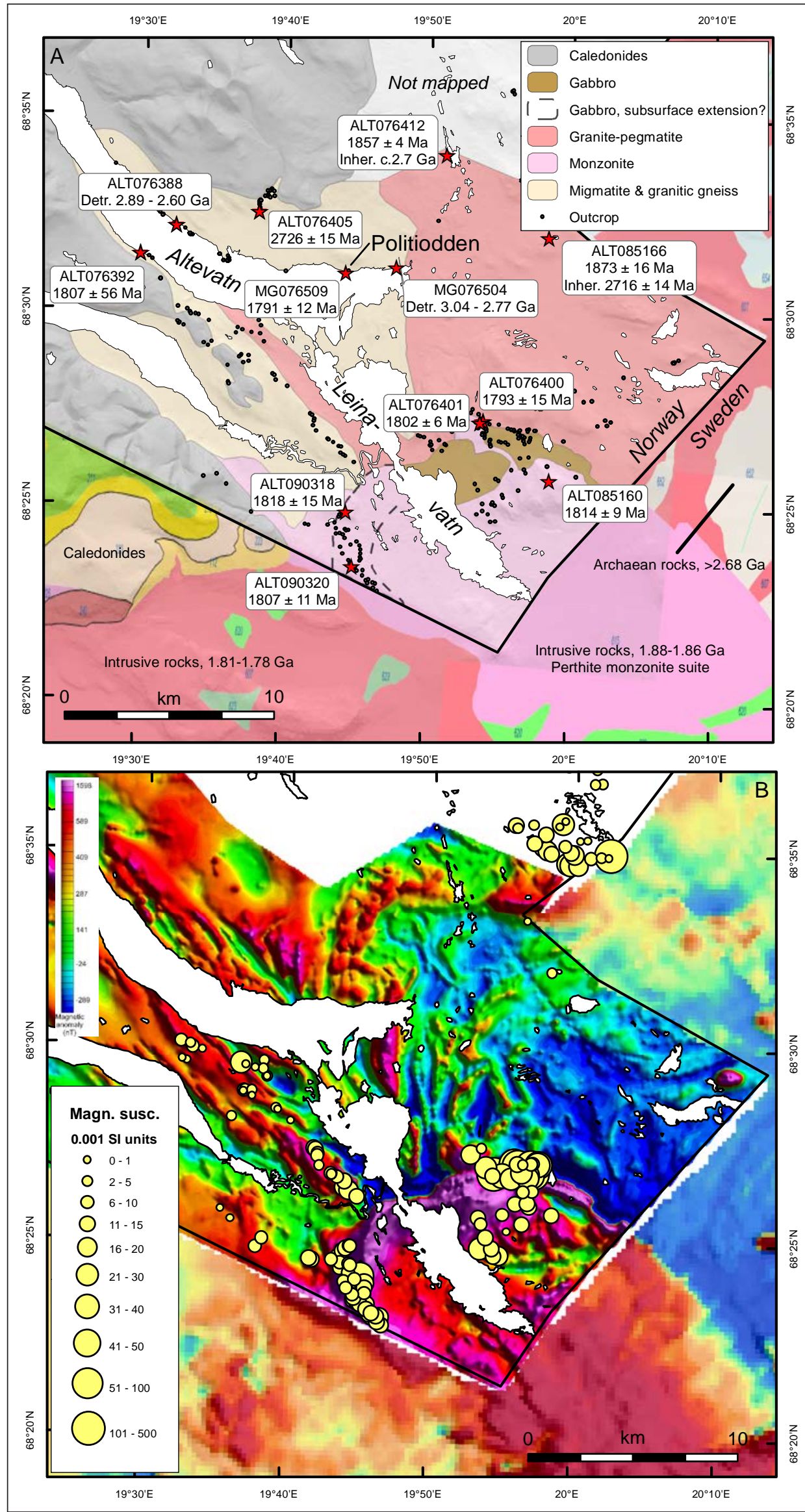

Figure 2. (A) Geological map of the Altevatn area, based on four field seasons of mapping and newly obtained aeromagnetic data (Ofstad \& Stampolidis, 2014) shown in (B). Also shown in (B) are measured magnetic susceptibilities (see Table 1 for summary and details). Rock types (A) and geophysical data (B) from Sweden from Bergman et al. (2001). 


\section{Lithologies, field relationships and structures in the Altevatn area}

The Altevatn area is mostly covered by thick moraine, and outcrop is restricted to sporadic fresh exposures along the shores of the regulated Altevatn lake as well as more weathered exposures on and around nearby peaks. The varying water levels in Altevatn offer lichenfree, unweathered exposure, but almost exclusively of the Archaean migmatitic rocks. The younger intrusions of monzonite and granite, and the gabbro in particular, have only been studied in more or less weathered outcrops away from Altevatn.

Fig. 2 shows a new geophysical and geological map of the Altevatn area, based on mapping by NGU over the last four field seasons. The magnetic data were collected within the framework of the MINN project, and have been analysed from a qualitative point of view. The accuracy of the data is on the order of $2 \mathrm{nT}$. The average flight clearance was $70 \mathrm{~m}$, line separation was $200 \mathrm{~m}$ (NNESSW orientation) and the distance between the measurement points was $c .5 \mathrm{~m}$. The magnetic anomaly is given with reference to the International Geomagnetic Reference Field 2010 (IGRF-2010). Aeromagnetic data for the Altevatn area have been interpolated to a $50 \times 50 \mathrm{~m}$ grid. Due to the high latitude of the area investigated, no reduction to the pole has been applied.

The poor exposure in the Altevatn area makes the geophysical data analysis crucial for the definition of tectonic elements. In the aeromagnetic map (Fig. 2B), a zone of long-wavelength, low-amplitude magnetic anomalies characterises the north-northwestern segment of the area, which coincides with the Caledonides in Fig. 2A. The granite-pegmatite unit is characterised by negative magnetic anomalies of short wavelengths. Migmatites and granitic gneisses in the central part of the area exhibit positive magnetic anomalies of low amplitude and higher frequencies compared to the Caledonides, while a similar magnetic signature may be seen for the monzonites in the southern segment of the area. The most striking feature of the magnetic map is a high-magnetic, E-W-striking, curved anomaly (c. $9000 \mathrm{nT}$ ) that matches gabbro outcrops north of Leinavatn lake. These magnetic anomalies suggest a west- to southward extension of the gabbro and possible Fe-mineralisations (magnetite).

\section{Archaean metatexites and diatexites}

The shores along Altevatn offer sporadic, but spectacular exposure of strongly migmatitic, gneissic rocks. As discussed below, both supracrustal and plutonic protoliths may be inferred; however, in most cases identification of protoliths is rendered difficult by the high degrees of partial melting.
The stromatic metatexites are medium- to coarse-grained biotite gneisses with well-developed gneissic textures and sparse to abundant granitic leucosomes (Fig. 3A). The foliation is generally moderately to steeply SW dipping (Fig. 4B), and defined by sheets of leucosome and metamorphic segregations in the rock. Sheets of fine-grained, homogeneous amphibolite, several metres in thickness and concordant to the foliation in the metatexites, are common and interpreted to represent former mafic dykes based on their general homogeneity. Similar mafic sheets are not found in the surrounding Palaeoproterozoic granitoid rocks, providing a minimum age of $c .1 .8 \mathrm{Ga}$ for the dykes. Granitic leucosomes are typically concordant with the foliation, although different degrees of discordance are observed suggesting that melting took place during deformation. Syndeformation melting is indicated by numerous decimetre-long, melt-filled shear bands and boudin necks (Fig. 3B, C). Although the proportion of leucosome locally exceeds $50 \%$, these structural relationships suggest a rock-dominated rather than melt-dominated rheology, the defining characteristic between meta- and diatexite, respectively (Sawyer, 2008 and references therein).

The protolith(s) to the metatexites cannot be determined with certainty. Locally, the metatexites are characterised by a somewhat diffuse, $\mathrm{cm}$-thick, compositional layering defined by varying proportions of biotite, which may reflect a primary layering but could also result from metamorphic segregation. Locally, the metatexites are associated with quartzite, which could be taken as evidence of a supracrustal origin for the metatexite protolith. Although it is possible that the metatexites formed the basement on which the quartzite protolith was deposited, the $\mathrm{U}-\mathrm{Pb}$ zircon data presented below suggest that at least some of the metatexites have sedimentary protoliths. In the diatexites, rare blocks of calc-silicate rocks have been observed (Fig. 3D), which also points to a supracrustal origin. Taken together, the field observations suggest that at least some of the migmatites have supracrustal protoliths.

Unlike the metatexites, the diatexites do not show any signs of coherent structural behaviour, such as folds or shear bands, and are characterised by structurally incoherent, mm-thick and dm-long, biotite-rich schlieren and randomly rotated blocks of resister lithologies (Fig. 3D, E). The diatexites lack continuous sheets of amphibolite, but contain numerous, $\mathrm{dm}$ - to $\mathrm{m}$-size, angular amphibolite fragments that most likely represent disrupted amphibolite sheets, similar to those found in the metatexites. In many cases, the amphibolite fragments are surrounded by pegmatite (Fig. 3F), interpreted to reflect melt migration towards low-pressure sites around the rheologically stronger fragments.

The Archaean granites and granitic gneisses are typically heterogeneous, and where strain is relatively low, several-metre to decimetre-long lenses of metatexite are observed, that in some places extend into biotite- 

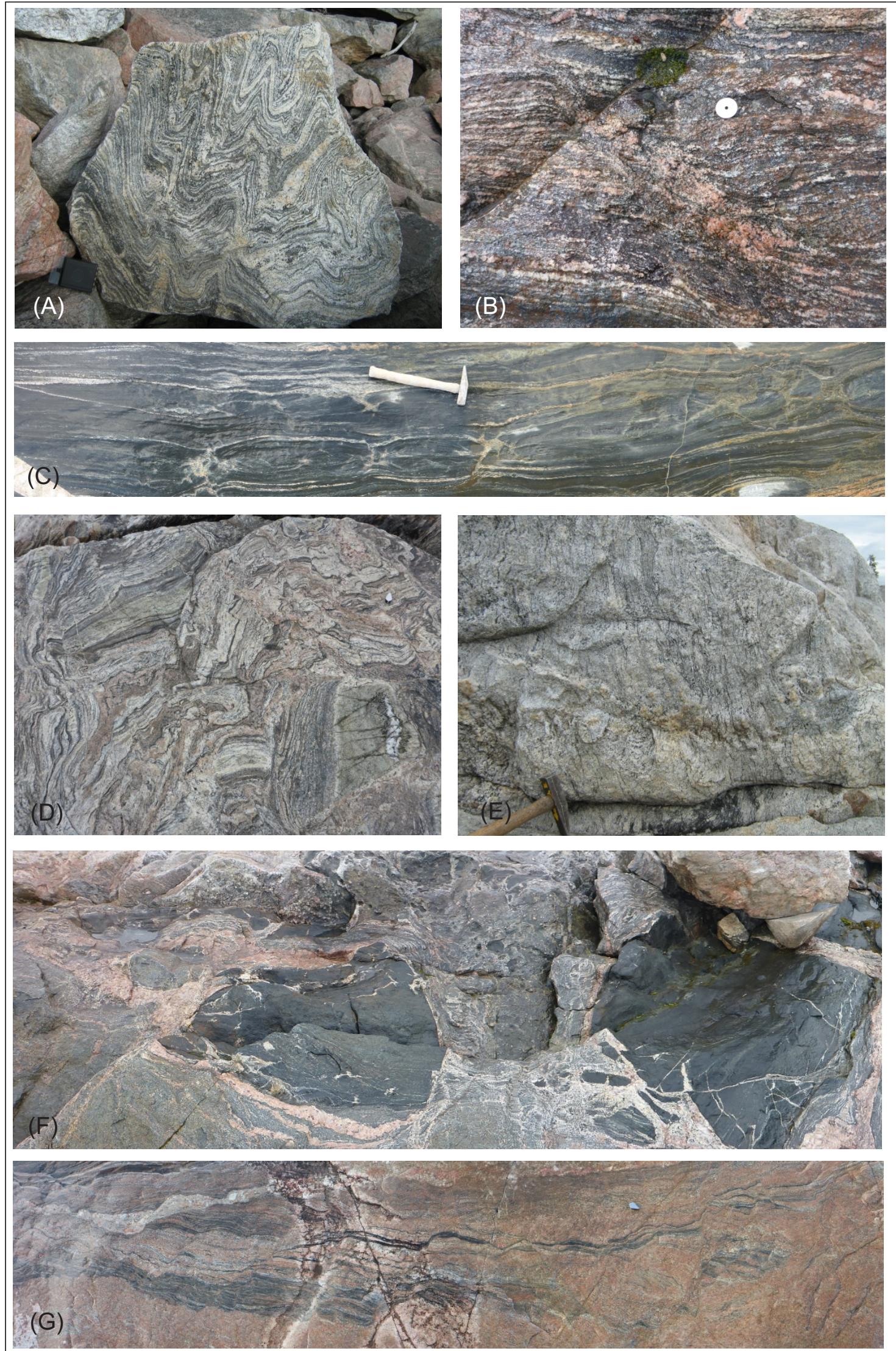

Figure 3. (A) Stromatic migmatite (metatexite) with folded, granitic leucosomes. Melt-filled shear band (B) and boudin necks (C) in stromatic migmatite, suggesting that melting was synchronous with deformation. (D) Blocks of more resistant calc-silicate gneiss in diatexite. The rotation of the individual blocks shows that the rock had a magma-like rheology. (E) Abundant bt-rich schlieren in diatexite, also attesting to wholesale magma-like flow. (F) Pegmatitic material collecting around blocks of amphibolite in the diatexite. This relationship is interpreted to reflect melt sucked into the low-pressure zones that would have developed around the strong amphibolite blocks during synmelting deformation. $(G)$ Granite, with fragments of migmatite stretched into schlieren in the granitic magma. 


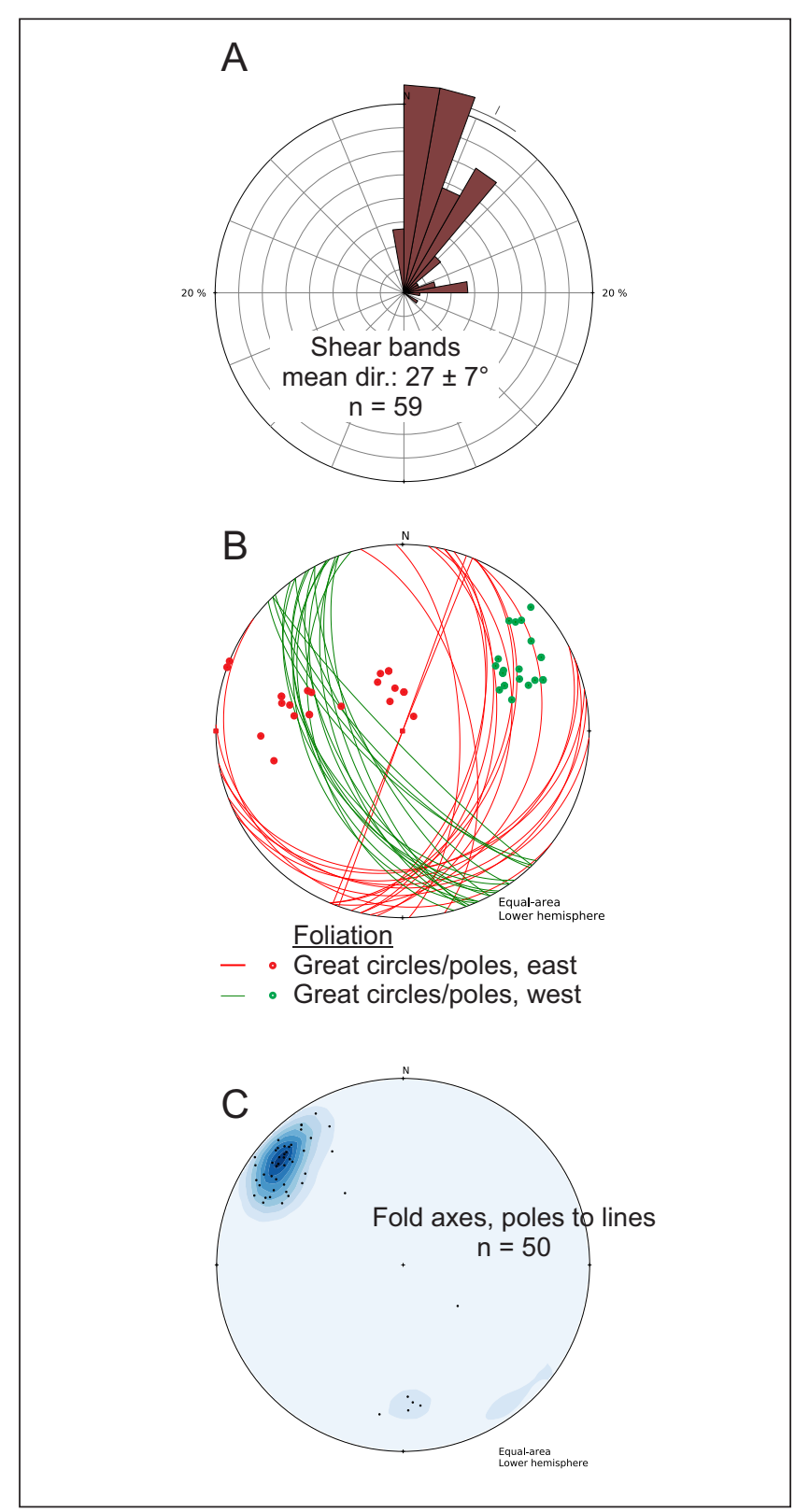

Figure 4. Structural data from the stromatic migmatites along the Altevatn shores.

rich schlieren (Fig. 3G). Although field relationships that demonstrate a genetic relationship between meta-/ diatexite and the granitic gneisses have not been found, the above relationships, along with the geochronological data presented below, suggest that such a link is likely and that the area may preserve evidence of the migmatite to granite transition described elsewhere (e.g., Sawyer, 1996). Further work, however, is needed to substantiate this assertion.

The migmatites and Archaean granitic gneisses yield relatively low magnetic susceptibilities, with an average of 0.009 SI units (Table 1), comparable to that of Archaean gneisses in the Norrbotten Province (Bergman et al., 2001).
Table 1. Average magnetic susceptibility of the rocks in the Altevatn area.

\begin{tabular}{ll}
\hline Rock type & $\begin{array}{l}\text { Avg. magn. susc. } \\
\pm \text { st. dev. }(n)\end{array}$ \\
\hline Gabbro & $76 \pm 113(42)$ \\
Monzonite & $24 \pm 40(71)$ \\
Granite-pegmatite & $16 \pm 32(97)$ \\
Migmatite \& granitic gneiss (Archaean) & $9 \pm 11(161)$
\end{tabular}

${ }^{1} 10^{-3}$ SI units.

Measurements were carried out with a handheld SM20 magnetic susceptibility meter from GF Instruments.

\section{Structures}

The Palaeoproterozoic rocks described below are largely undeformed, and structural observations are therefore restricted to small, sporadic migmatite outcrops along the northern shore of Altevatn.

The orientations of 59 leucosome-filled shear bands were measured. The glaciated shores of Altevatn made measurements of dip difficult, and the orientations of the shear bands have therefore been plotted in a rose diagram (Fig. 4A). In the few cases where dip could be recorded, it was typically subvertical. The shear bands dominantly display a dextral sense of shear of the foliation, but are locally associated with sinistral shear bands (Fig. 5B). The dominant population of dextral shear bands is oriented NNE-SSW, whereas the sinistral shear bands typically have a more northeasterly orientation.

Foliations east of Politiodden (see Fig. 2 for location) dip moderately to shallowly between $\mathrm{E}$ and SE, whereas foliations west of Politiodden dip moderately to steeply SW, defining a large, open fold with a shallowly SSE-plunging fold axis (Fig. 4B). Fold axes of the dm-scale tight folds plunge shallowly NW, roughly parallel to the largescale fold (Fig. 4C), and probably represent a small-scale expression of the same fold geometry.

Most of the NNE-SSW-oriented dextral shear-bands were observed west of Politiodden, in an area with moderately to steeply SW-dipping foliations. This geometrical relationship is compatible with formation of the foliation and dextral shear bands during orthogonal, NE-SW-oriented compression.

The structures in the migmatites can be divided into two groups, where the older group appears to have formed during melting and the younger group to postdate melting. The synmelting group includes melt-filled shear bands and boudin necks, whereas the younger, postmelting group includes the folded leucosomes of 


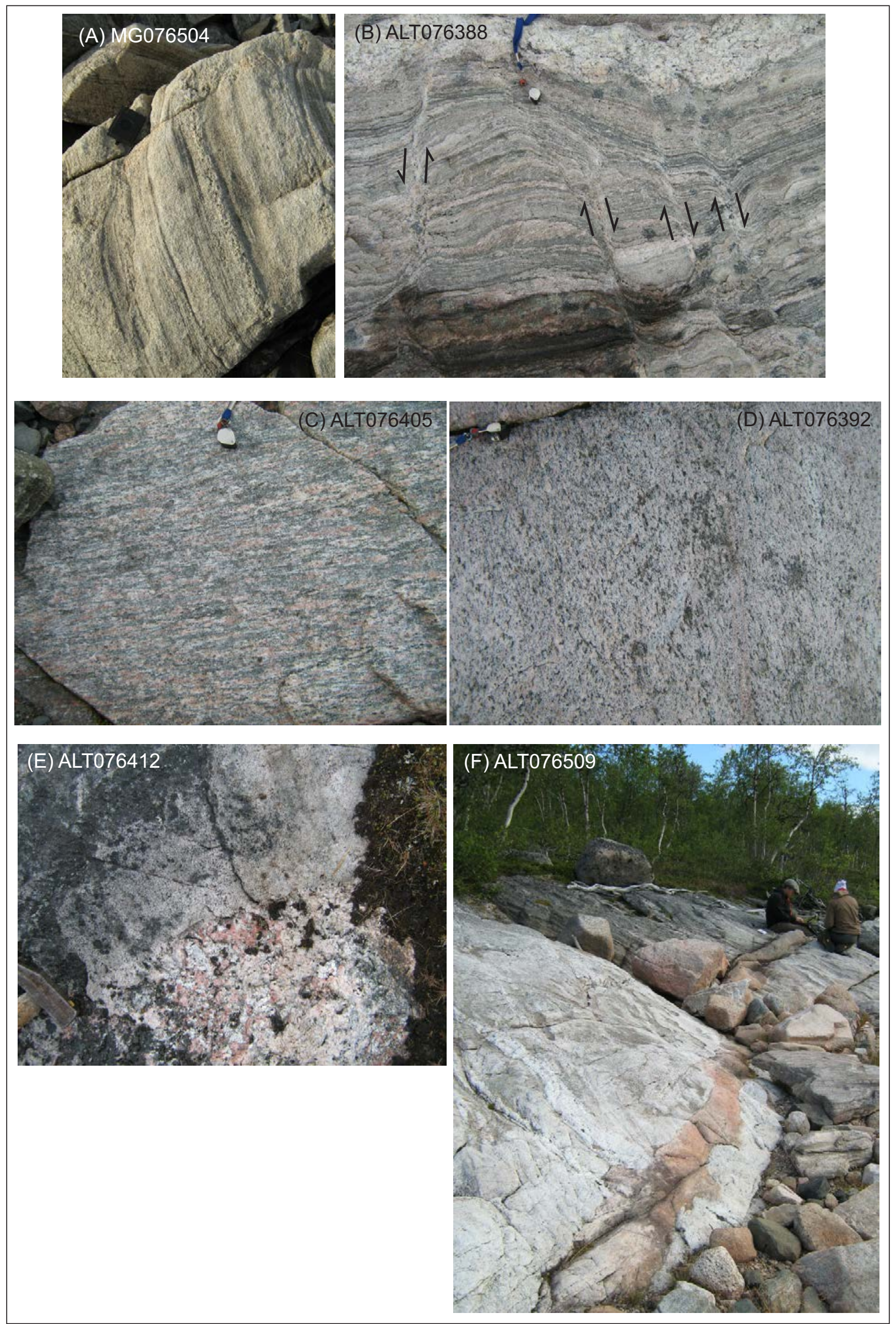

Figure 5. Field photos of dated samples. Arrows in (B) denote senses of shear of melt-filled shear bands. 
the stromatic migmatites. Some uncertainty surrounds the conjecture that folding post-dated melting; in particular, the varying degrees of leucosome concordance to the foliation in the rocks suggest that melting occurred during folding. On the other hand, no axial-planar, leucosome veins have been observed, which would be expected if folding took place in the presence of melt (e.g., Sawyer, 2008).

\section{Palaeoproterozoic intrusive rocks}

Three types of intrusive plutonic rock have been identified in the eastern Altevatn area: monzonite, gabbro and granite-pegmatite. These rocks are exposed only in scattered, small outcrops and the gabbros, in particular, are typically strongly weathered. In addition, fine-grained, pale-red granitic dykes are found in numerous places cutting the metamorphic fabrics in the Archaean migmatites.

\section{Gabbro}

Gabbro is found north of Leinavatn lake (Fig. 2A) and probably extends southwards below and beyond the lake, judging from the high-magnetic anomaly (Fig. 2B). The proportion of plagioclase and mafic minerals is variable and the gabbro varies from leucogabbro to olivine twopyroxene melagabbro. The gabbro is typically coarse grained and displays a subophitic texture with interstitial orthopyroxene and clinopyroxene crystals containing laths of euhedral plagioclase (Fig. 6A, B). Olivine is present in a few samples as a subhedral phase and is surrounded by pyroxene suggesting that olivine was an early crystallising phase in the system. Symplectites of opaque minerals and orthopyroxene are also commonly found in the centre of the pyroxene oikocrysts, indicating that olivine was once stable in these samples as well. Opaque minerals are subhedral to interstitial and can account for $10-20 \%$ of the rock. Apatite is commonly found associated with these opaque minerals; however, in a couple of samples, apatite is found as a euhedral phase partly surrounded by oikocrystic pyroxenes. Apatite can be up to several millimetres in length, and may constitute several percent of the rock in some samples.

The gabbro yields high magnetic susceptibilities, with an average of 0.076 SI units (Table 1), similar to the more mafic lithologies of the Perthite monzonite suite in the Norrbotten Province (Bergman et al., 2001).

\section{Monzonite}

Monzonite is mainly found south of Leinavatn (Fig. 2), and is coarse grained. It contains between 60 and $90 \%$ of micro- and mesoperthitic blocky ternary feldspar, and quartz is present as interstitial films between the blocky feldspars and rarely constitutes more than a few percent of the modal composition (Fig. 6C, D). Mafic minerals occur as clusters with relics of pale-green clinopyroxene surrounded by green amphibole. Apatite, zircon and opaque minerals are found associated with the mafic minerals. Opaque minerals are commonly anhedral and contain inclusions of euhedral zircon and apatite. The proportion of accessory minerals in the rock varies from one sample to another. One of the samples is slightly different as both plagioclase and K-feldspar were stable instead of ternary feldspar. The other textural and mineral characteristics for that sample are similar to what is observed in the other monzonite samples. Several samples show evidence of retrogression with transformation of pyroxene to actinolite, and hornblende to biotite and actinolite. Opaque minerals are rimmed by titanite. This mineral assemblage is characteristic of greenschist-facies conditions. Most of the retrogression is not associated with deformation and could be related to fluid circulation during the emplacement of the Caledonian nappes a few kilometres away (Fig. 2A).

The monzonite yields relatively high magnetic susceptibilities, with an average of 0.024 SI units (Table 1), comparable to the more felsic parts of the Perthite monzonite suite (Bergman et al., 2001).

\section{Granite-pegmatite}

Granite-pegmatite is found north and east of Altevatn, and typically shows gradations from coarse-grained granite to pegmatite. The rocks commonly contain both subhedral plagioclase and K-feldspar (typically microcline), surrounded by anhedral quartz (Fig. 6E, F). Both feldspars are perthitic, indicating that they do not result from recrystallisation of ternary feldspar at subsolidus temperatures. Mesoperthitic feldspar is present in a few samples. Mafic minerals are sparse, but where present consist of biotite and green hornblende, the latter containing quartz inclusions suggesting that it formed from transformation of pyroxene. Apatite and zircon are locally abundant and present as 0.5 to $1 \mathrm{~mm}$ euhedral crystals. The distribution of the accessory minerals is highly variable from one sample to the other, which could be an effect of the coarse grain size. A single thinsection might, therefore, not be representative.

In some samples, mafic minerals are retrogressed into biotite, chlorite, epidote and titanite, typical of greenschist-facies overprinting. Allanite is also a secondary phase in many samples. The retrogression seems to be related to fluid circulation with static recrystallisation rather than deformation, as only a local foliation defined by a few biotite grains has been observed. The granitepegmatites are undeformed and, in rare cases, contain large xenoliths or rafts of migmatite.

The granite-pegmatite yields relatively intermediate to low magnetic susceptibilities, with an average of 0.016 SI units (Table 1), which is similar to that reported for the Granite-pegmatite suite in the Norrbotten Province (Bergman et al., 2001). 

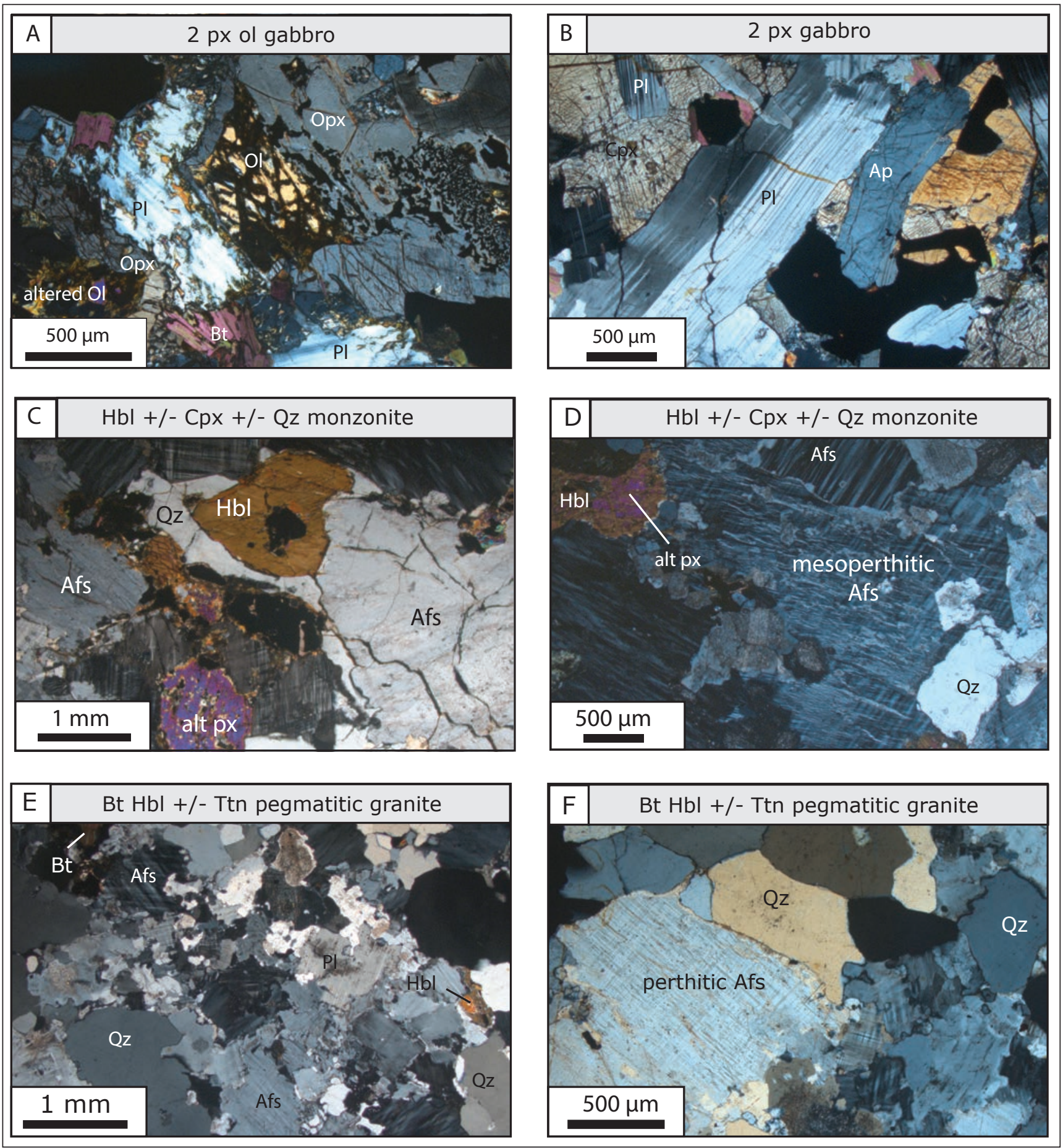

Figure 6. Thin-section photomicrographs of the investigated igneous rocks. (A) Relict olivine crystal surrounded by orthopyroxene in a gabbro. (B) Oikocrystic gabbroic texture with euhedral plagioclase laths surrounded by anhedral pyroxene. Note the large euhedral apatite crystal. (C) Relict pyroxene in hornblende, alkali feldspar and interstitial quartz in monzonite. (D) Mesoperthitic potassium feldspar in monzonite. (E) Textural relationship between feldspar, quartz and mafic minerals in granite. (F) Perthitic potassium feldspar and quartz in granite. Mineral abbreviations from Whitney \& Evans (2010).

Fine-grained, pale-red granitic dykes

Fine-grained, pale-red granitic dykes, typically only a few dm thick, cut the Archaean migmatites in several places along Altevatn (Fig. 5F). The dykes are undeformed. 


\section{Methods}

\section{Whole-rock geochemistry}

Major- and trace-element compositions were determined on fused glass beads and pressed powder pellets, respectively, on a Philips PW 1480 X-ray spectrometer (XRF) at the Geological Survey of Norway (NGU), using international standards (Govindaraju, 1984, 1989).

\section{Geochronology}

Zircons were separated by standard techniques including water table, heavy liquids, magnetic separation and final hand picking under a binocular microscope. The zircons were mounted in epoxy and polished to approximately half thickness, and cathodoluminescence (CL) images were obtained with a scanning electron microscope to reveal internal structures such as growth zoning and core-rim relationships.

\section{SIMS}

SIMS (Secondary Ion Mass Spectrometer) analyses were performed on the Cameca IMS 1270 SIMS at the Nordsim laboratory, Swedish Museum of Natural History, Stockholm. The analytical method, data reduction, error propagation and assessment of the results are outlined in Whitehouse et al. (1999) and Whitehouse \& Kamber (2005). The analyses were conducted with an $\mathrm{O}_{2}$-beam of $4 \mathrm{nA}$ and a spot size of $10-30 \mu \mathrm{m}$, calibrated to the Geostandard 91500 reference zircon with an age of 1065 Ma (Wiedenbeck et al., 1995). The error on the U/Pb ratio includes propagation of the error on the day-today calibration curve obtained by regular analysis of the reference zircon. A common- $\mathrm{Pb}$ correction was applied using the ${ }^{204} \mathrm{~Pb}$ concentration and present-day isotopic composition (Stacey \& Kramers, 1975).

\section{LA-ICP-MS}

LA-ICP-MS (Laser Ablation Inductively Coupled Mass Spectrometry) analyses were carried out at NGU, under the auspices of CAMOC (Centre for Advanced Mineral and Ore Characterisation, at NGU and NTNU in Trondheim). The instrument is an ELEMENT XR single collector, high-resolution ICP-MS, coupled to a UP193-FX $193 \mathrm{~nm}$ short-pulse excimer laser ablation system from New Wave Research. The laser was set to ablate single, up to $60 \mu \mathrm{m}$-long lines, using a spot size of 20 or $15 \mu \mathrm{m}$, a repetition rate of $10 \mathrm{~Hz}$ and an energy corresponding to a fluence of $4-5 \mathrm{~J} / \mathrm{cm}^{2}$. Each analysis included $30 \mathrm{~s}$ of background measurement followed by $30 \mathrm{~s}$ of ablation. The masses 202, 204, 206-208, 232 and 238 were measured. The reference material GJ-1 (Jackson et al., 2004) was used for correction of isotopic ratios, whereas 91500 (Wiedenbeck et al., 1995) and an in-house standard (OS-99-14; $1797 \pm 3$ Ma; Skår, 2002) were used to check precision and accuracy. The data were not corrected for common lead, but monitoring of the signal for 204 allowed exclusion of affected data from further calculations. The data were reduced using the GLITTER ${ }^{\circledast}$ software (Van Achterbergh et al., 2001).

All samples were dated by SIMS, except samples ALT090318, ALT090320, ALT085166 and ALT085160. The Isoplot program (Ludwig, 2003) was used to regress and present the $\mathrm{U}-\mathrm{Pb}$ isotope data from both methods. The geochronological data are presented in Electronic Supplement 1.

\section{Geochronological results}

MG076504 (n4284), diffusely banded quartz-plagioclase-biotite gneiss

The sample is from a fine-grained quartz-plagioclasebiotite gneiss (Fig. 5A). The gneiss has a faint, rather diffuse, $\mathrm{cm}$-scale compositional banding defined by varying amounts of biotite, and contains a few $\mathrm{cm}$-thick, coarsegrained granitic leucosomes that vary from concordant to discordant to the gneiss fabric, locally intruding along small shear bands.

The zircons from this sample range from equant, through stubby, to prismatic (Fig. 7A). Some grains are rounded with truncation of internal zoning, whereas other grains show little or no rounding. Grain size varies between $c$. 100 and $150 \mu \mathrm{m}$. Most grains display oscillatory zoning; none of the grains show evidence of metamorphic overgrowths, but one grain displays recrystallisation from the edge towards the core (Fig. 7A).

Sixteen analyses are concordant and yield ${ }^{207} \mathrm{~Pb} /{ }^{206} \mathrm{~Pb}$ ages ranging from 2668 to $3036 \mathrm{Ma}$ (Fig. 8A). Three analyses are strongly discordant, whereas the recrystallised core yields a $6 \%$ discordant age of $2384 \mathrm{Ma}$. These data suggest that the protolith to the quartz-plagioclase-biotite gneiss may be a sedimentary rock, as indicated by the compositional layering observed in this sample, with a maximum depositional age of c. 2.7 Ga. No clear metamorphic overprinting is recorded in the zircons, apart from the recrystallised core; however, due to the discordance, the age of this event is unclear.

\section{ALT076388 (n4283), \\ light-grey metatexite gneiss}

The sample is from a strongly migmatitic, light-grey, biotite-bearing gneiss with abundant $1-2 \mathrm{~cm}$-thick, palered leucosomes with thin mafic selvedges (Fig. 5B). The sampled rock contains numerous, small, left- and righthanded shear bands in which the foliation is obliterated by leucosome that probably represents melt that collected in the low-pressure shear bands. The rocks are generally not 

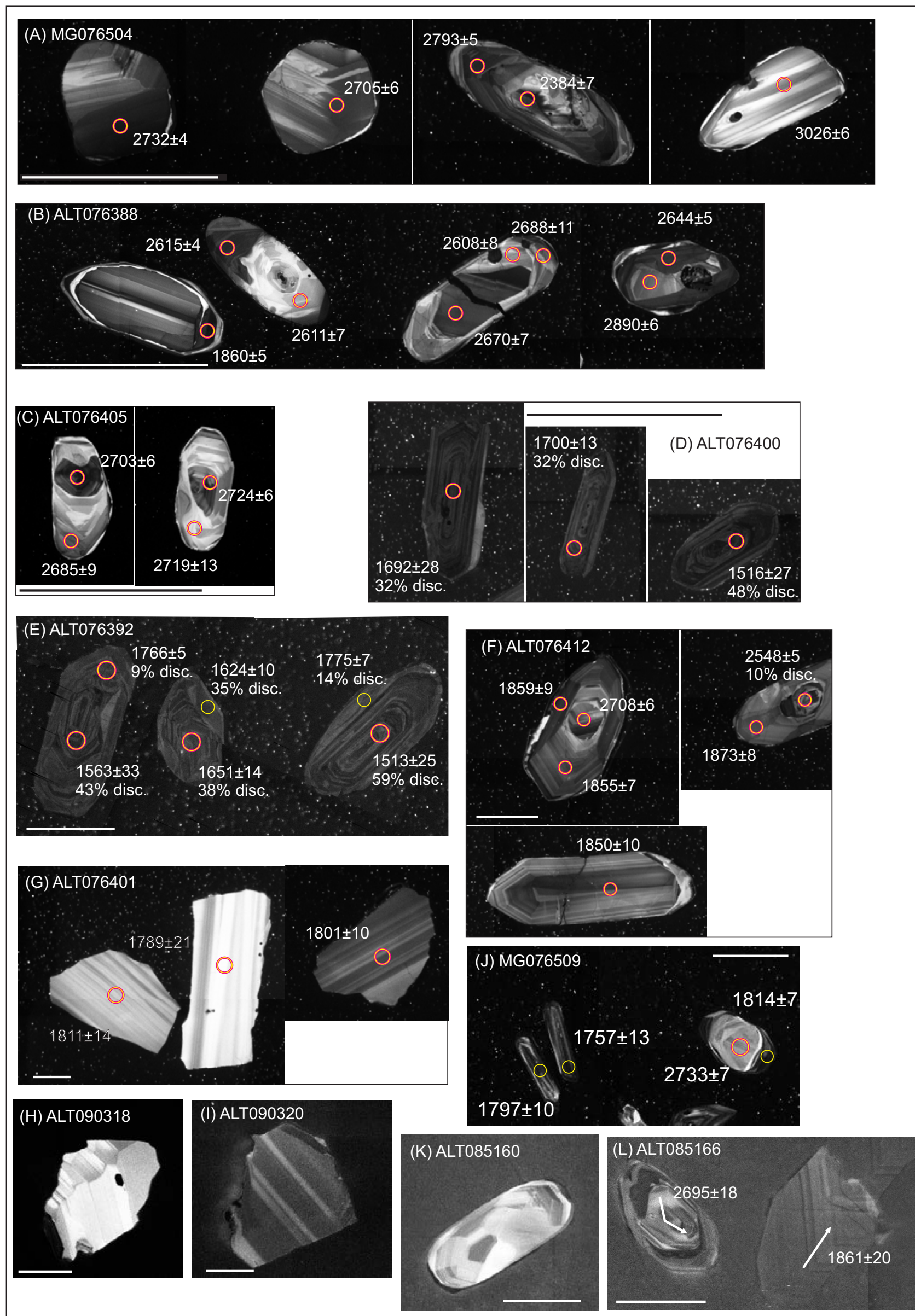

Figure 7. CL images of dated zircons with SIMS analytical spots and LA-ICP-MS analytical lines, and corresponding ${ }^{207} \mathrm{~Pb} /{ }^{206} \mathrm{~Pb} a g e$. 
diatexitic, although locally wholesale flow appears to have taken place. The migmatite contains a c. $5 \mathrm{~m}$-wide pod of amphibolite, and the migmatite is cut by a $c .1 \mathrm{~m}$-thick irregular sheet of fine-grained, reddish-grey granite (same as sample ALT076509, described below). A rather faint, $\mathrm{cm}$-thick, light- to medium-grey layering is locally preserved in the migmatite, similar to that observed in the quartz-plagioclase-biotite gneiss (sample MG076504).

The zircons from this sample are equant to prismatic, and range in size from c. 50 to $150 \mu \mathrm{m}$ (Fig. 7B). Most of the grains are oscillatory or sector zoned, and some grains have oscillatory-zoned cores mantled by oscillatoryzoned zircon that truncates the zoning in the core. Other grains have thinner, CL-dark featureless rims or grain tips.

Sixteen analyses of oscillatory-zoned cores and mantles yield ages mainly between 2.60 and $2.70 \mathrm{Ga}$, with one core yielding an older age of $2890 \pm 6 \mathrm{Ma}$ (Fig. 8B). The mantles tend to be at the younger end of the age spectrum; however, many of the mantles yield discordant analyses rendering discussions of any systematic variation speculative. The rims and grain tips yield ages around $1860 \mathrm{Ma}$.

Interpreting these data is inherently difficult. One possible interpretation is that the cores reflect crystallisation of the protolith (or deposition of a sediment derived from a c. 2.70 Ga source), followed shortly thereafter by high-grade metamorphism and migmatisation, as reflected by the oscillatory-zoned mantles. The rims and grain tips may reflect a younger $c$. $1.86 \mathrm{Ga}$ metamorphic event, for example related to emplacement of nearby granitoids (see below). Another possibility is that the oscillatory-zoned cores and mantles reflect growth and resorption processes in the magma that eventually formed the protolith to the light-grey gneiss, and that the rims and grain tips reflect the age of high-grade metamorphism and migmatisation. For reasons discussed below, we regard the first interpretation as the most likely.

\section{ALT076405 (n4285), coarse-grained granitic gneiss}

This sample comes from an area characterised by rather heterogeneous, coarse-grained, granite and granitic gneiss, locally with xenoliths of amphibolite and migmatite. The granitic gneiss is characterised by a coarse texture defined by $\mathrm{cm}$-thick, irregular, elongate patches rich in red K-feldspar, separated by a biotite- and amphibolerich 'matrix' (Fig. 5C).

The zircons from this sample are irregularly prismatic, range in size between 100 and $200 \mu \mathrm{m}$ and have welldeveloped oscillatory zoning (Fig. 7C). Many of the grains have CL-dark, oscillatory-zoned cores, truncated by CL-lighter, oscillatory-zoned mantles.
Eighteen analyses cluster around 2.70 Ga, one analysis is discordant and one analysis is reversely discordant (Fig. 8C). Excluding the reversely discordant analysis, a discordia through the remaining 19 analyses yields an upper-intercept age of $2726 \pm 15 \mathrm{Ma}$ and a lower-intercept age of $1823 \pm 99 \mathrm{Ma}$. There is no systematic difference in age between CL-dark cores and CL-lighter mantles, both yielding indistinguishable ages around $2.70 \mathrm{Ga}$.

Similarly to the light-grey metatexite gneiss (sample ALT076388), the data can be interpreted as reflecting $c$. $2.70 \mathrm{Ga}$ high-grade metamorphism of an only slightly older protolith, with a later metamorphic event at $c$. $1.82 \mathrm{Ga}$ reflecting emplacement of nearby granitoids. Another interpretation could be that the $c$. 2.70 Ga cores and mantles represent magmatic growth, resorption and regrowth in a $2.70 \mathrm{Ga}$ magma, followed by high-grade metamorphism at c. $1.82 \mathrm{Ga}$. We tentatively interpret the upper-intercept age of $2726 \pm 15 \mathrm{Ma}$ to represent the age of the granitic protolith, and the lower-intercept age of $c$. $1.8 \mathrm{Ga}$ to represent a thermal and/or fluid event related to emplacement of the surrounding granitoids.

\section{ALT076400 (n4286), granite (granite-pegmatite suite)}

This sample is from a medium- to coarse-grained, reddish-grey granite with scattered specks of biotite.

The zircons from this sample are generally prismatic, between 100 and $300 \mu \mathrm{m}$, and display CL-dark, oscillatory-zoned interiors (Fig. 7D). Some grains have dark cores with lighter rims, whereas other grains have lighter cores surrounded by dark rims. The zircons are rich in $\mathrm{U}$, up to $4000 \mathrm{ppm}$, and many of the zircons are probably partly metamict and have undergone $\mathrm{Pb}$ loss. In addition, the zircons are high in common $\mathrm{Pb}$, as shown by the vertically elongate error ellipses in the Tera-Wasserburg plot (below).

Excluding two analyses with very high common $\mathrm{Pb}$ (of which only one is shown in the plot), the remaining 20 analyses define a discordia with an upper intercept of $1793 \pm 15 \mathrm{Ma}$, and a lower intercept of $363 \pm 34 \mathrm{Ma}$ (Fig. $8 \mathrm{D})$. These ages are interpreted to reflect the crystallisation age of the granite and late-Caledonian $\mathrm{Pb}$ loss, respectively.

\section{ALT076392 (n4289), granite (granite-pegmatite)}

This sample is from a medium- to coarse-grained granite with 1-2 cm disperse stripes of biotite. The granite is locally porphyritic with 1-2 cm subangular to rounded K-feldspar phenocrysts, and in places displays some compositional heterogeneity, with diffuse patches rich in biotite (Fig. 5D). 

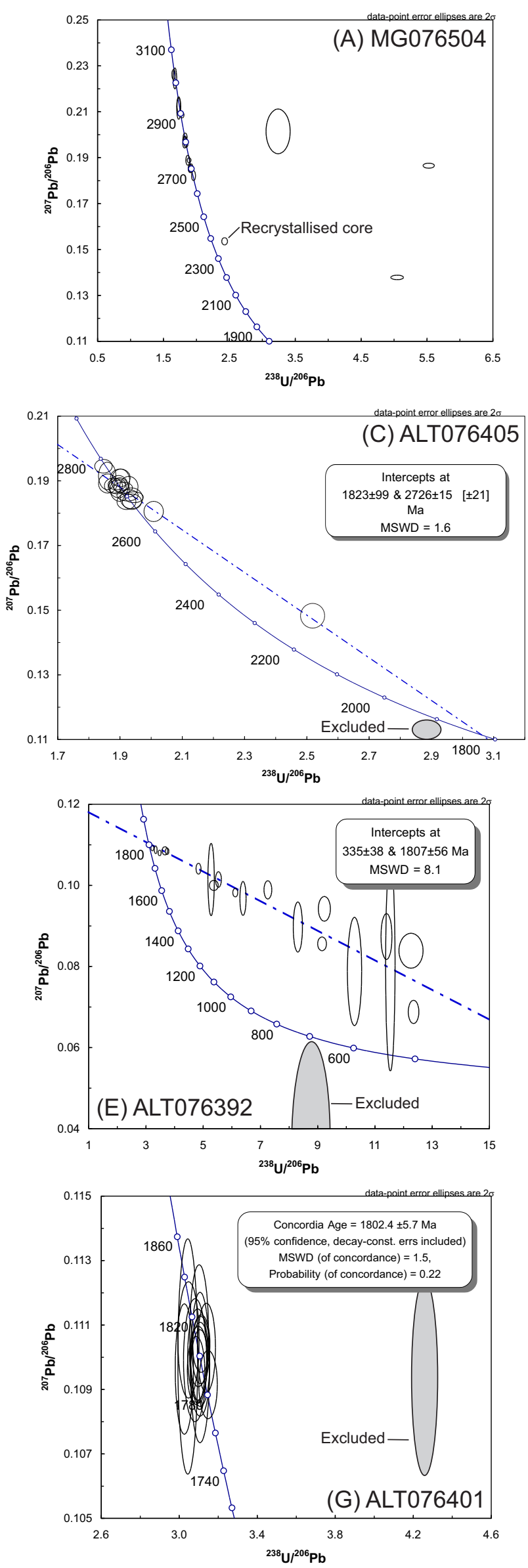
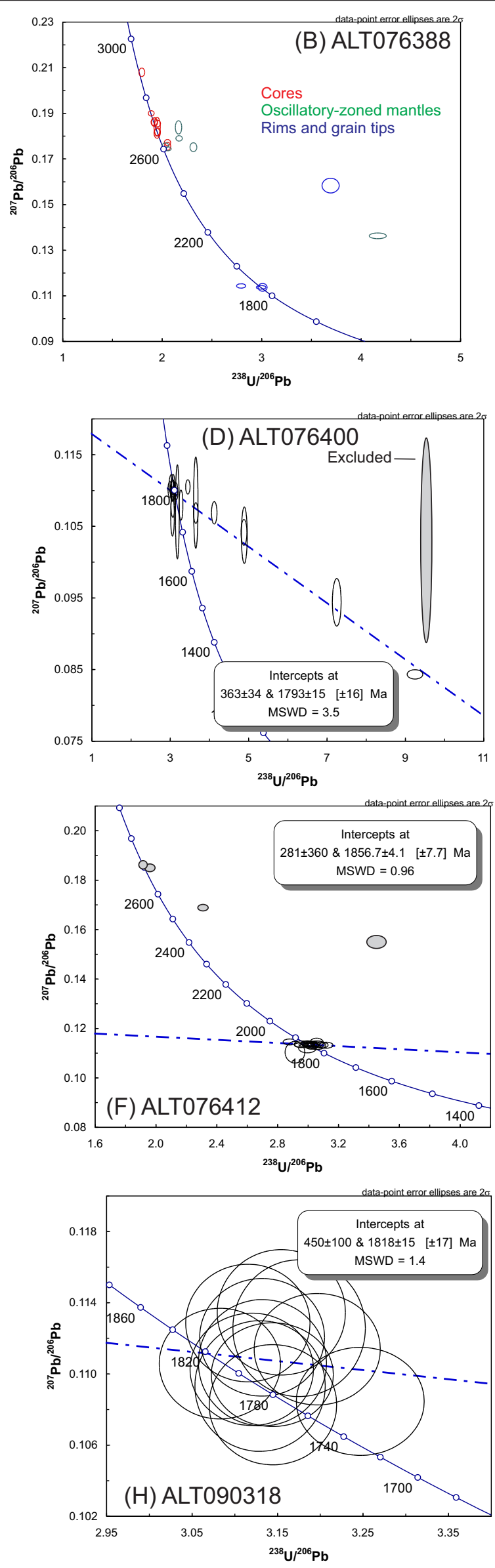

Figure 8. Tera-Wasserburg plots presenting the U-Pb zircon isotopic data. 

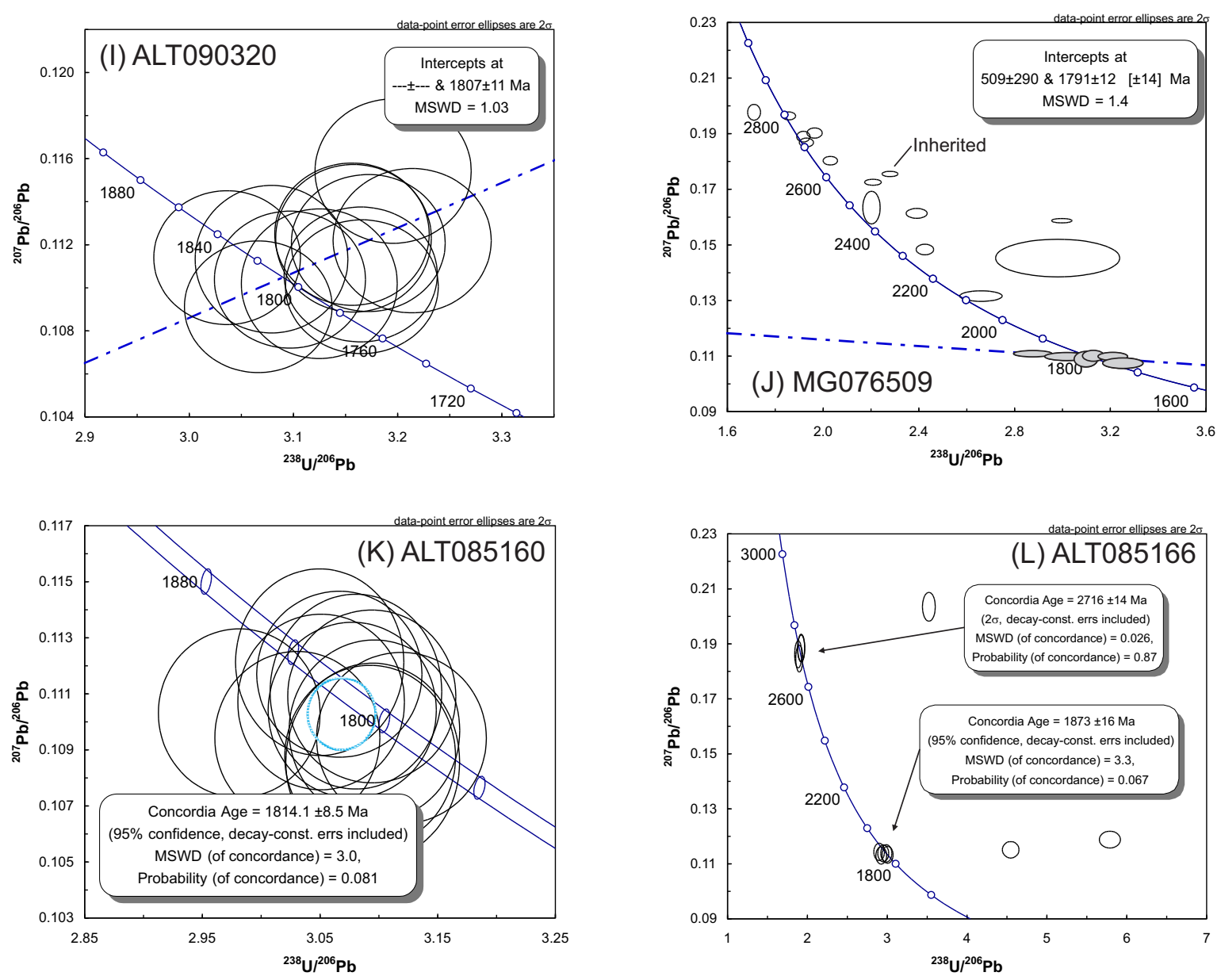

Figure 8. Continued. Tera-Wasserburg plots presenting the U-Pb zircon isotopic data.

The zircons from this sample are all prismatic, between 100 and $300 \mu \mathrm{m}$, and have CL-dark, finely oscillatoryzoned interiors (Fig. 7E). As for sample ALT076400, the zircons are rich in $\mathrm{U}$ and have undergone $\mathrm{Pb}$ loss. The vertically elongate error ellipses in the Tera-Wasserburg plot (Fig. 8E) also suggest high common $\mathrm{Pb}$.

Excluding one analysis with excessive common $\mathrm{Pb}$, the remaining 19 analyses yield a discordia with an upper intercept of $1807 \pm 56 \mathrm{Ma}$ and a lower intercept of $335 \pm$ $38 \mathrm{Ma}$ (Fig. 8E), interpreted to reflect the crystallisation age and late-Caledonian $\mathrm{Pb}$ loss, respectively.

\section{ALT076412 (n4291), granite-pegmatite}

This sample is from the northern part of an extensive unit of granite-pegmatite, in which the transitions from medium- and coarse-grained granite to pegmatite may be either sharp or gradational (Fig. 5E).

The zircons from this sample are all nicely prismatic, range in size from c. 150 to $400 \mu \mathrm{m}$, and display oscilla- tory and sector zoning, in some cases with small oscillatory-zoned cores (Fig. 7F).

The cores yield ages of $2.70 \mathrm{Ga}$, or are strongly discordant, suggesting an inherited component from the nearby Archaean gneisses and migmatites (Fig. 8F). The remaining 18 analyses cluster around $1850 \mathrm{Ma}$ and define a discordia with an upper intercept of $1857 \pm$ 4 and a lower intercept of $281 \pm 360 \mathrm{Ma}$. The former is interpreted to represent the age of crystallisation of the granite-pegmatite, whereas the significance of the latter, if any, is unclear but permissive of Caledonian $\mathrm{Pb}$ loss, as observed in some of the other dated samples.

\section{ALT085166, granite-pegmatite}

The sampled rock and zircons are similar to that described for sample ALT076412 (Fig. 7L).

Zircon cores in this sample yield a concordia age of $2716 \pm 14 \mathrm{Ma}$, whereas oscillatory-zoned mantles and grains yield a concordia age of $1873 \pm 16 \mathrm{Ma}$ (Fig. 8L), 
interpreted to reflect inheritance and crystallisation age, respectively. The age overlaps with that of sample ALT076412.

\section{ALT076401 (n4292), monzonite}

This sample is from a coarse-grained, red monzonite with unevenly distributed, $\mathrm{cm}$-size specks of hornblende and biotite, possibly representing altered pyroxene. The rock is undeformed.

Most zircons from this sample are $150-300 \mu \mathrm{m}$ fragments of larger zircons, with well-developed oscillatory zoning (Fig. 7G).

Excluding one discordant analysis, the remaining 15 concordant analyses yield a Concordia age of $1802 \pm 6$ $\mathrm{Ma}$ (Fig. 8G), interpreted as the crystallisation age of the monzonite.

\section{ALT0903 18, monzonite}

The sampled rock and zircons are similar to that described for sample ALT076401 (Fig. 7H).

Twelve analyses yield concordant to weakly discordant data that spread from 1820 to $1750 \mathrm{Ma}$. An upper-intercept age of $1818 \pm 15 \mathrm{Ma}$ (Fig. $8 \mathrm{H}$; MSWD = 1.4), with an anchored Caledonian lower intercept of $450 \pm 100 \mathrm{Ma}$, is interpreted to represent the best estimate of the crystallisation age of the monzonite.

\section{ALT090320, monzonite}

The sampled rock and zircons are similar to that described for sample ALT076401 (Fig. 7I).

Twelve analyses yield concordant to discordant data clustering around $1800 \mathrm{Ma}$, and intercept the concordia at $1807 \pm 11 \mathrm{Ma}$ (Fig. 8I; MSWD = 1.03), interpreted as the age of crystallisation of the monzonite.

\section{ALT085160, monzonite}

The sampled rock is similar to that described for sample ALT076401.

The zircons from this sample are oscillatory and sector zoned, and typically prismatic, ranging in size between 100 and $300 \mu \mathrm{m}$ (Fig. 7K).

Twelve analyses yield concordant data, with a Concordia age of $1814 \pm 9 \mathrm{Ma}$ (Fig. 8K), interpreted to represent the age of crystallisation of the monzonite.
MG076509 (n4290), fine-grained granitic dyke

This sample is from a $20-30 \mathrm{~cm}$-thick, fine-grained granite dyke cutting the contact between tonalitic migmatite and quartzite (Fig. 5F). The contact is folded by an open, shallowly SE-plunging fold, and the dyke thus provides a minimum age for this deformation. Similar granite dykes are seen everywhere within the migmatites, as discussed above, and in this case provides a minimum age for the deformation as well as for the deposition of the quartzite.

The zircons from this sample display a range of morphologies ranging from thin, prismatic to more stubby (Fig. 7J). Most grains are oscillatory zoned, and many have partly resorbed cores mantled by relatively thick, oscillatory-zoned zircon.

Several analyses from the cores yield ages between 2.70 and $2.80 \mathrm{Ga}$; however, most are rather strongly discordant but without yielding a well-defined discordia (Fig. $8 J)$. Six near-concordant to slightly reversely discordant analyses from prismatic, oscillatory-zoned grains or mantles define a discordia with an upper intercept of $1791 \pm 12 \mathrm{Ma}$ and a lower intercept of $509 \pm 290 \mathrm{Ma}$. The upper intercept is interpreted to reflect crystallisation of the granitic dyke whereas the lower intercept age may reflect Caledonian $\mathrm{Pb}$ loss. Most of the zircons in this dyke appear to be inherited from the surrounding Archaean host rocks.

\section{Geochemistry of high-magnetic gabbro}

Table 2 presents $\mathrm{Fe}_{2} \mathrm{O}_{3}, \mathrm{TiO}_{2}, \mathrm{P}_{2} \mathrm{O}_{5}$ and $\mathrm{V}$ data from seven samples of the high-magnetic gabbro. Limited exposure of the easily weathered gabbro has hampered more thorough sampling, and the dataset should only be taken as indicative of the gabbro as a whole. $\mathrm{Fe}_{2} \mathrm{O}_{3}$ contents are highly variable, ranging from 8 to $39 \mathrm{wt} . \%, \mathrm{TiO}_{2}$ ranges from 0.6 to $4.2 \mathrm{wt} . \%, \mathrm{P}_{2} \mathrm{O}_{5}$ from 0.6 to $1.6 \mathrm{wt} . \%$ and $\mathrm{V}$ from 100 to nearly $600 \mathrm{ppm}$. Vanadium and Ti are positively correlated with $\mathrm{Fe}$, which is not surprising considering they are most likely linked to the amount of iron oxide, whereas $\mathrm{P}$ is randomly distributed with respect to $\mathrm{Fe}$ (plots not shown here). The highest Fe concentrations from the gabbro are somewhat below the lower range for the Kiruna apatite iron ores, whereas the P contents overlap (e.g., Jonsson et al., 2013; Lundh, 2014). The concentrations of $\mathrm{Fe}_{2} \mathrm{O}_{3}, \mathrm{TiO}_{2}, \mathrm{P}_{2} \mathrm{O}_{5}$ and $\mathrm{V}$ overlap with those of some economic deposits elsewhere in the world, such as the Damiao deposit in the North China Craton (Xie, 1982; Zhao et al., 2009; Charlier et al., 2015), which contains average concentrations (Altevatn gabbro maximum concentrations in parentheses): 36 wt. $\% \mathrm{Fe}_{2} \mathrm{O}_{3}$ (39 wt.\%), 7 wt.\% $\mathrm{TiO}_{2}$ (4.2 wt.\%), 2300 ppm V (588 ppm), 2 wt.\% 
Table 2. Whole-rock chemical data from the high-magnetic gabbro east of Altevatn.

\begin{tabular}{ccccccc}
\hline Sample & UTM_E & UTM_N & $\begin{array}{c}\mathrm{Fe}_{2} \mathrm{O}_{3} \\
(w t . \%)\end{array}$ & $\begin{array}{c}\mathrm{TiO}_{2} \\
(w t . \%)\end{array}$ & $\begin{array}{c}\mathrm{P}_{2} \mathrm{O}_{5} \\
(w t . \%)\end{array}$ & $\begin{array}{c}\mathrm{V} \\
(\boldsymbol{p} \text { pm })\end{array}$ \\
\hline 90302 & 446897 & 7594078 & 7.93 & 0.58 & 0.58 & 109 \\
90303 & 446962 & 7593497 & 8.00 & 0.69 & 0.52 & 122 \\
85161 & 457428 & 7593480 & 14.6 & 2.16 & 1.42 & 244 \\
85162 & 457384 & 7593478 & 24.5 & 3.30 & 0.79 & 521 \\
85163 & 456843 & 7593114 & 11.8 & 1.64 & 0.65 & 181 \\
85164 & 456893 & 7593163 & 38.6 & 4.17 & 1.17 & 588 \\
98774 & 457383 & 7593511 & 15.0 & 2.36 & 1.57 & 254 \\
\hline
\end{tabular}

UTM coordinates apply to zone 34.

$\mathrm{P}_{2} \mathrm{O}_{5}$ (1.57 wt.\%). The Damiao data are taken from Sun et al. (2009). Although comparing maximum values from one area with average values from another does not give a correct impression of the grade of the former, it shows that the gabbro may contain economically interesting concentrations of these elements and may form a potential future target for exploration.

\section{Geological evolution of the Altevatn area and regional considerations}

The high-grade migmatitic rocks appear to have supracrustal, and possibly also igneous, protoliths formed at c. $2.70 \mathrm{Ga}$, and later intruded by c. 1.86 to 1.79 Ga granitoids and gabbro. This is consistent with earlier work in the Norrbotten Province that has identified both ortho- and paragneisses with c. $2.7 \mathrm{Ga}$ protoliths, and younger, Palaeoproterozoic intrusive rocks (Welin et al., 1971; Skiöld, 1979; Skiöld \& Page, 1998; Martinsson et al., 1999). This evolution is also similar to that described farther west, in the West Troms Basement Complex and in Lofoten-Vesterålen (e.g., Corfu, 2004; Bergh et al., 2012; Myhre et al., 2013), consistent with recent hypotheses linking the Lapland-Kola and Karelia cratons of northern Fennoscandia with the West Troms Basement Complex/Lofoten-Vesterålen (Bergh et al., 2012), with the Altevatn area in a geographically intermediate position.

Structurally, the evolution in the Altevatn area appears to be characterised by early, synmigmatisation deformation, followed by lower-grade folding about shallowly plunging NW- and SE-oriented fold axes. The age of high-grade metamorphism and extensive partial melting is poorly defined in our dataset, but is clearly older than $1.86 \mathrm{Ga}$, which is the age of the oldest undeformed and unmetamorphosed granite in the Altevatn area. The U$\mathrm{Pb}$ zircon data indicate that a high-grade metamorphic event may have affected the rocks shortly after protolith formation between $c$. 2.70 and $2.60 \mathrm{Ga}$, similar to that documented in the WTBC (Myhre et al., 2013) and the Lofoten-Vesterålen area (Corfu, 2007). More work is underway to better constrain the age of high-grade metamorphism in the Altevatn area.

The age range of late Svecofennian magmatism observed in the Altevatn area $(1.86-1.79 \mathrm{Ga})$ matches perfectly with that documented for the Lofoten-Vesterålen, WTBC and RTW (Corfu, 2004; Angvik, 2014), adding to the geographical extent of this already widespread magmatic event. This event included emplacement of a petrologically distinct ortho- and/or clinopyroxene-bearing suite of rocks in Lofoten-Vesterålen, generally referred to as mangerite, but which locally only has clinopyroxene (Coint, unpublished data, 2015). These rocks are similar to the monzonite in the Altevatn area in terms of petrography and age. This rock type has not been described from the WTBC farther to the northeast, where gabbroic and in particular granitic rocks dominate (Zwaan et al., 1998). The granitic rocks have not been studied in great detail, however, but Corfu et al. (2003) described the Ersfjord granite in the central part of the WTBC as "slightly heterogeneous in terms of grain size and abundance of biotite", which makes it potentially similar to the granite-pegmatite from Altevatn. The age of $1792 \pm 5 \mathrm{Ma}$ reported for the Ersfjord granite (Corfu et al., 2003) is similar to parts of the granite-pegmatite suite in the Altevatn area. The significance of this difference in magma composition between the Lofoten-Vesterålen area, WTBC and the Altevatn area is unknown, but may relate to different positions within a geographically extensive magmatic system. Further work, including whole-rockand mineral chemistry and isotopes, is needed to elucidate the processes behind this major magmatic event. It appears, however, that Svecofennian accretion along the southwestern margin of Fennoscandian was waning at this time (Bergh et al., 2010), and that this widespread, c. 1.8 $\mathrm{Ga}$, magmatic event heralded the birth of a very long-lived active continental margin (Roberts \& Slagstad, 2015).

As discussed in the Introduction, earlier work in the Fennoscandian Shield proper, RTW and WTBC has documented voluminous, widespread volcanism and sedimentation related to ocean closure and related arc/ back-arc processes at around $1.9 \mathrm{Ga}$. So far, no such rocks or metamorphic/deformational effects related to such processes have been identified in the Altevatn area. A possible exception is the NW-SE-trending fold structures documented in the migmatites, which may match those observed in the WTBC (Bergh et al., 2010), RTW (Angvik, 2014) and Kautokeino Greenstone Belt (Henderson et al., 2015). As of now, we do not have strict age constraints on the timing of this event, apart from a cross-cutting granitic dyke yielding a $1791 \pm 12 \mathrm{Ma}$ minimum age for this event. None of the surrounding granitoids, the oldest of which are c. $1.86 \mathrm{Ga}$, appear to have been deformed, which may, therefore, represent a somewhat older minimum age of deformation. However, 
considering the general lack of exposure and complete lack of cross-cutting relationships, this interpretation is uncertain. These structural/intrusive constraints allow for c. 1.9 Ga Svecofennian deformation in the Altevatn area; however, it is equally possible that the deformation may be Late Archaean.

Although there are numerous similarities between the Altevatn area and the Lofoten-Vesterålen and WTBC warranting a westward continuation of Fennoscandia beneath the Caledonian nappes, recent work in the Mauken basement window (Fig. 1) poses some issues (Bjerkgård et al., 2015). The geochronological data from Mauken show a range of granitoid crystallisation ages between 1.9 and $2.8 \mathrm{Ga}$, including some at 2.1 and 2.4 Ga. These ages are all but absent from Altevatn, Lofoten-Vesterålen and the WTBC, but exist in other parts of Fennoscandia where they are typically interpreted to reflect rifting and fragmentation of the Archaean cratonic nucleus (Lahtinen et al., 2008). These data suggest the possibility that there is a concealed tectonic contact between the Altevatn area and similar units to the west, related to Svecofennian amalgamation. More work involving interpretation of geophysical data and structural, metamorphic and geochronological investigations of the Mauken and other Caledonian basement windows is needed to shed light on this very interesting issue.

\section{Metallogenic potential of the Altevatn area}

As discussed above, the main mineralisations of the Norrbotten Province and RTW are found in c. 1.9 Ga, lowgrade supracrustal rocks. No such rocks have been identified in the Altevatn area, nor in the Dividalen area to the north (Slagstad \& Willemoes-Wissing, unpublished field data, 2015), thus the potential for finding similar mineral occurrences in these areas appears to be small.

So far, the most interesting target for follow-up work is the undated gabbro north of Leinavatn, which possibly extends south, below and beyond Leinavatn, as suggested by the high-magnetic anomaly in this area (Fig. 2B). The gabbro is typically strongly weathered and crops out in only a few places; thus, the chemical dataset is limited, but shows interesting concentrations of Fe, P, V and Ti. Assessing the metallogenic potential of this gabbro requires a rather extensive drilling programme through locally thick Quaternary deposits. Although gabbros of similar age (assuming that the undated gabbro in the Altevatn area is c. 1.9-1.8 Ga) are known in the WTBC, the LofotenVesterålen area and the Norrbotten Province (Bergman et al., 2001; Corfu, 2004; Kullerud et al., 2006a), economically significant mineralisations related to such rocks have not been reported (cf., Eilu, 2012). It is worth mentioning that $\mathrm{Ti}-\mathrm{V}-\mathrm{Fe}$ mineralisations, roughly similar in grade to those in the gabbro at Altevatn, have been found in a noritic gab- bro of the Perthite monzonite suite (Akkavare, $40 \mathrm{~km}$ west of Gällivare) and a tholeiitic sill of the Greenstone group (Airikurkkio, $9 \mathrm{~km}$ northwest of Vittangi).

\section{Conclusions}

The Altevatn area consists of high-grade, metatexitic to diatexitic Neoarchaean rocks that were intruded by voluminous, c. $1.8 \mathrm{Ga}$ granitoids. This evolution is similar to that documented for other parts of the Norrbotten Province to the east, and the West Troms Basement Complex, Lofoten-Vesterålen area, Rombak Tectonic Window and Kautokeino Greenstone Belt to the west, south and north, respectively. Rocks with economically interesting mineralisations, e.g., similar to those found in Kiruna, have not been identified in the Altevatn and Dividalen areas, and the metallogenic potential thus appears to be low, although a high-magnetic gabbro may prove an interesting target for future follow-up work.

Acknowledgements. Silje Nørsett and Karsten Sedal Slagstad are thanked for valuable assistance during mapping and sampling. Pasi Eilu and Raimo Lahtinen generously provided a digital copy of Fig. 1. Lev Ilyinski and Martin Whitehouse provided invaluable help with the SIMS analyses at NORDSIM, and Torkil Røhr and Øyvind Skår provided assistance during LA-ICP-MS analyses at NGU. Discussions with Iain Henderson, Are Korneliussen, Tine Larsen Angvik and Kerstin Saalmann, and comments from reviewers Per Inge Myhre and Lars Eivind Augland helped improve the manuscript significantly. Per Terje Osmundsen is thanked for editorial handling of the manuscript. This is NORDSIM contribution no. 458, and CAMOC contribution no. 1.

\section{References}

Angvik. 2014: Structural development and metallogenesis of Paleoproterozoic volcano-sedimentary rocks of the Rombak Tectonic Window. $\mathrm{PhD}$ thesis, University of Tromsø, $248 \mathrm{pp}$.

Bergh, S.G., Kullerud, K., Corfu, F., Armitage, P.E.B., Davidsen, B., Johansen, H.W., Pettersen, T. \& Knudsen, S. 2007: Low-grade sedimentary rocks on Vanna, North Norway: a new occurrence of a Palaeoproterozoic (2.4-2.2 Ga) cover succession in northern Fennoscandia. Norwegian Journal of Geology 87, 301-318.

Bergh, S.G., Kullerud, K., Armitage, P.E.B., Zwaan, K.B., Corfu, F., Ravna, E.J.K. \& Myhre, P.I. 2010: Neoarchaean to Svecofennian tectono-magmatic evolution of the West Troms Basement Complex, North Norway. Norwegian Journal of Geology 90, 21-48.

Bergh, S.G., Corfu, F., Myhre, P.I., Kullerud, K., Armitage, P.E.B., Zwaan, K.B., Ravna, E.J.K., Holdsworth, R.E. \& Chattopadhya, A. 2012: Was the Precambrian basement of Western Troms and LofotenVesterålen in northern Norway linked to the Lewisian of Scotland? A comparison of crustal components, tectonic evolution and amalgamation history. Intech 283-330.

Bergh, S.G., Kullerud, K., Myhre, P.I., Corfu, F., Armitage, P.E.B., Zwaan, K.B. \& Ravna, E.J.K. 2014: Archaean Elements of the Basement Outliers West of the Scandinavian Caledonides in Northern Norway: Architecture, Evolution and Possible Correlation with 
Fennoscandia. In Dilek, Y. \& Furnes, H. (eds.): Evolution of Archean Crust and Early Life Springer Netherlands, Dordrecht, pp. 103-126.

Bergman, S., Kübler, L. \& Martinsson, O. 2001: Description of Regional Geological and Geophysical Maps of Northern Norrbotten County (east of the Caledonian Orogen) Ba 56, Sveriges geologiska undersökning, $114 \mathrm{pp}$.

Berthelsen, A. \& Marker, M. 1986: Tectonics of the Kola collision suture and adjacent Archaean and Early Proterozoic terrains in the northeastern region of the Baltic Shield. Tectonophysics 126, 31-55.

Bjerkgård, T., Slagstad, T., Henderson, I.H.C., Sandstad, J.S. \& Schönenberger, J. 2015: Geology and gold mineralisation in the Mauken basement window, Måselv, Troms. Norwegian Journal of Geology 95, 423-443. http://dx.doi.org/10.17850/njg95-3-08.

Braathen, A. \& Davidsen, B. 2000: Structure and stratigraphy of the Palaeoproterozoic Karasjok Greenstone Belt, north Norway regional implications. Norsk Geologisk Tidsskrift 80, 33-50.

Charlier, B., Namur, O., Bolle, O., Latypov, R. \& Duchesne, J.-C. 2015: $\mathrm{Fe}-\mathrm{Ti}-\mathrm{V}-\mathrm{P}$ ore deposits associated with Proterozoic massif-type anorthosites and related rocks. Earth-Science Reviews 141, 56-81.

Corfu, F., Armitage, P.E.B., Kullerud, K. \& Bergh, S.G. 2003: Preliminary $\mathrm{U}-\mathrm{Pb}$ geochronology in the West Troms Basement Complex, North Norway: Archaean and Palaeoproterozoic events and younger overprints. Norges Geologiske Undersøkelse Bulletin 441, 61-72.

Corfu, F. 2004: U-Pb age, setting and tectonic significance of the anorthosite-mangerite-charnockite suite, Lofoten-Vesterålen, Norway. Journal of Petrology 45, 1799-1819.

Corfu, F. 2007: Multistage metamorphic evolution and nature of the amphibolite-granulite facies transition in Lofoten-Vesterålen, Norway, revealed by $\mathrm{U}-\mathrm{Pb}$ in accessory minerals. Chemical Geology $241,108-128$.

Daly, J.S., Balagansky, V.V., Timmerman, M.J. \& Whitehouse, M.J. 2006: The Lapland-Kola orogen: Palaeoproterozoic collision and accretion of the northern Fennoscandian lithosphere. Geological Society, London, Memoirs 32, 579-598.

Eilu, P. (ed.) 2012: Mineral deposits and metallogeny of Fennoscandia. Geological Survey of Finland, Special Paper 53, 401 pp.

Govindaraju, K. 1984: Compilation of working values and sample description for 170 international reference samples of mainly silicate rocks and minerals. Geostandards Newsletter 8, 1-91.

Govindaraju, K. 1989: Compilation of working values and sample description for 272 geostandards. Geostandards Newsletter Special Edition 13,1-113.

Hallberg, A., Bergman, T., Gonzalez, J., Larsson, D., Morris, G.A., Perdahl, J.A., Ripa, M., Niiranen, T. \& Eilu, P. 2012: Metallogenic areas in Sweden. In Eilu, P. (ed.): Mineral deposits and metallogeny of Fennoscandia, Geological Survey of Finland Special Paper 53, Geological Survey of Finland, pp. 139-206.

Henderson, I.H.C, Viola, G. \& Nasuti, A. 2015: A new tectonic model for the Kautokeino Greenstone Belt, northern Norway, based on high-resolution airborne magnetic data and field structural analysis and implications for mineral potential. Norwegian Journal of Geology 95, 339-363. http://dx.doi.org/10.17850/njg95-3-05.

Högdahl, K., Andersson, U.B. \& Eklund, O. (eds.) 2004: The Transscandinavian Igneous Belt (TIB) in Sweden: a review of its character and evolution. Geological Survey of Finland, Special Paper 37, 123 pp.

Hölta, P., Balagansky, V.V., Garde, A.A., Mertanen, S., Peltonen, P., Slabunov, A.I., Sorjonen-Ward, P. \& Whitehouse, M.J. 2008: Archean of Greenland and Fennoscandia. Episodes 31, 13-19.

Jackson, S.E., Pearson, N.J., Griffin, W.L. \& Belousova, E.A. 2004: The application of laser ablation-inductively coupled plasma-mass spectrometry to in situ U-Pb zircon geochronology. Chemical Geology 211, 47-69.

Jonsson, E., Troll, V.R., Högdahl, K., Harris, C., Weis, F., Nilsson, K.P. \& Skelton, A. 2013: Magmatic origin of giant 'Kiruna-type' apatiteiron-oxide ores in Central Sweden. Scientific Reports 3, 1644.

Kaulina, T.V., Yapaskurt, V.O., Presnyakov, S.L., Savchenko, E.E. \&
Simakin, S.G. 2010: Metamorphic evolution of the archean eclogite-like rocks of the Shirokaya and Uzkaya Salma area (Kola Peninsula): Geochemical features of zircon, composition of inclusions, and age. Geochemistry International 48, 871-890.

Korja, A., Lahtinen, R. \& Nironen, M. 2006: The Svecofennian orogen: a collage of microcontinents and island arcs. Geological Society, London, Memoirs 32, 561-578.

Korneliussen, A. \& Sawyer, E.W. 1989: The geochemistry of Lower Proterozoic mafic to felsic igneous rocks, Rombak Window, North Norway. Norges Geologiske Undersøkelse Bulletin 415, 7-21.

Kullerud, K., Corfu, F., Bergh, S.G., Davidsen, B. \& Ravna, E.J.K. 2006a: $\mathrm{U}-\mathrm{Pb}$ constraints on the Archean and Early Proterozoic evolution of the West Troms Basement Complex, North Norway. The 27th Nordic geological wintermeeting, 9-12 January 2006, Oulu, Finland, p. 79.

Kullerud, K., Skjerlie, K.P., Corfu, F. \& de la Rosa, J.D. 2006b: The 2.40 Ga Ringvassøy mafic dykes, West Troms Basement Complex, Norway: The concluding act of early Palaeoproterozoic continental breakup. Precambrian Research 150, 183-200.

Kulling, O. 1964: Översikt över norra Norrbottensfjällens kaledonberggrund. Sveriges Geologiska Undersökning Ba 19, 1-166.

Lahtinen, R., Garde, A.A. \& Melezhik, V.A. 2008: Paleoproterozoic evolution of Fennoscandia and Greenland. Episodes 31, 20-28.

Lahtinen, R., Korja, A., Nironen, M. \& Heikkinen, P. 2009: Palaeoproterozoic accretionary processes in Fennoscandia. Geological Society, London, Special Publications 318, 237-256.

Ludwig, K.R. 2003: Isoplot 3.00, A Geochronological Toolkit for Microsoft Excel. Berkley Geochronology Center, Special Publication 4, 1-74.

Lundh, J. 2014: A lithogeochemical study of northern Sweden and the Kiruna and Malmberget iron-apatite ore deposits. MSc thesis, Uppsala university, 99 pp.

Martinsson, O. \& Perdahl, J.-A. 1995: Paleoproterozoic extensional and compressional magmatism in northern Sweden. In Perdahl, J.-A. (ed.): Svecofennian volcanism in northern Sweden, PhD thesis 1995:169D, Paper II Luleå University of Technology, pp. 1-13.

Martinsson, O., Vaasjoki, M. \& Persson, P.-O. 1999: U-Pb ages of Archaean to Palaeoproterozoic granitoids in the Torneträsk Råstojaure area, northern Sweden. In Bergman, S. (ed.): Radiometric dating results 4, Sveriges geologiska undersökning C831, pp. 70-90.

Mints, M.V., Belousova, E.A., Konilov, A.N., Natapov, L.M., Shchipansky, A.A., Griffin, W.L., O’Reilly, S.Y., Dokukina, K.A. \& Kaulina, T.V. 2010: Mesoarchean subduction processes: 2.87 Ga eclogites from the Kola Peninsula, Russia. Geology 38, 739-742.

Myhre, P.I., Corfu, F. \& Bergh, S. 2011: Palaeoproterozoic (2.0-1.95 Ga) pre-orogenic supracrustal sequences in the West Troms Basement Complex, North Norway. Precambrian Research 186, 89-100.

Myhre, P.I., Corfu, F., Bergh, S.G. \& Kullerud, K. 2013: U-Pb geochronology along an Archaean geotransect in the West Troms Basement Complex, North Norway. Norwegian Journal of Geology 93, 1-24.

Roberts, N.M.W. \& Slagstad, T. 2015: Continental growth and reworking on the edge of the Columbia and Rodinia supercontinents; 1.86-0.9 Ga accretionary orogeny in southwest Fennoscandia. International Geology Review 57, 1582-1606.

Romer, R.L., Kjøsnes, B., Korneliussen, A., Lindahl, I., Skyseth, T., Stendal, M. \& Sundvoll, B. 1992: The Archaean-Proterozoic boundary beneath the Caledonides of northern Norway and Sweden: U-Pb, $\mathrm{Rb}-\mathrm{Sr}$, and $\varepsilon \mathrm{Nd}$ isotope data from the Rombak-Tysfjord area. Geological Survey of Norway Report 91.225, 67 pp.

Romer, R.L., Martinsson, O. \& Perdahl, J.-A. 1994: Geochronology of the Kiruna iron ores and hydrothermal alterations. Economic Geology 89, 1249-1261.

Sawyer, E.W. 1996: Melt segregation and magma flow in migmatites: Implications for the generation of granite magmas. In Brown, M., Candela, P.A., Peck, D.L., Stephens, W.E., Walker, R.J. \& Zen, E. (eds.): Third Hutton Symposium The Origin of Granites and Related Rocks: Geological Society of America Special Paper 315, pp. 85-94.

Sawyer, E.W. 2008: Atlas of Migmatites. Canadian Mineralogist Special 
Publication 9, NRC Research Press and Mineralogical Association of Canada, $387 \mathrm{pp}$.

Skår, Ø. 2002: U-Pb geochronology and geochemistry of early Proterozoic rocks of the tectonic basement windows in central Nordland, Caledonides of north-central Norway. Precambrian Research 116, 265-283.

Skiöld, T. 1979: Zircon ages from an Archean gneiss province in northern Sweden. Geologiska Föreningens i Stockholm Förhandlingar 101, 169-171.

Skiöld, T. \& Cliff, R.A. 1984: Sm-Nd and U-Pb dating of Early Proterozoic mafic-felsic volcanism in northernmost Sweden. Precambrian Research 26, 1-13.

Skiöld, T. \& Öhlander, B. 1989: Chronology and geochemistry of late Svecofennian processes in northern Sweden. Geologiska Föreningens i Stockholm Förhandlingar 111,347-354.

Skiöld, T. \& Page, R.W. 1998: SHRIMP and isotope dilution zircon ages on Archaean basement-cover rocks in north Sweden. 23. Nordic Wintermeeting, 13-16 January, Århus, p. 273.

Skublov, S.G., Berezin, A.V. \& Mel'nik, A.E. 2011: Paleoproterozoic eclogites in the salma area, Northwestern Belomorian Mobile Belt: Composition and isotopic geochronologic characteristics of minerals and metamorphic age. Petrology 19, 470-495.

Slagstad, T., Roberts, N.M.W., Marker, M., Røhr, T.S. \& Schiellerup, H. 2013: A non-collisional, accretionary Sveconorwegian orogen. Terra Nova 25, 30-37.

Stacey, J.S. \& Kramers, J.D. 1975: Approximation of terrestrial lead isotope evolution by a two-stage model. Earth and Planetary Science Letters 26, 207-221.

Sun, J., Du, W., Wang, D., Li, J., Xu, G. \& Han, Y. 2009: Geological characteristic and genesis of the Heishan V-Ti magnetite deposit in Damiao, Chengde Hebei Province. Acta Geologica Sinica 83, 13441363.

Thelander, T. 1982: The Torneträsk Formation of the Dividal Group, northern Swedish Caledonides. Sveriges Geologiska Undersökning C789, 1-41.

Torgersen, E., Viola, G. \& Sandstad, J.S. 2015a: Revised structure and stratigraphy of the northwestern Repparfjord Tectonic Window, northern Norway. Norwegian Journal of Geology 95, 397-421. http://dx.doi.org/10.17850/njg95-3-06.

Van Achterbergh, E., Ryan, C.G., Jackson, S.E. \& Griffin, W.L. 2001: LAICP-MS in the Earth Sciences - Appendix 3, data reduction software for LA-ICP-MS. In Sylvester, P.J. (ed.): Short Course volume 29: St.John's, Mineralogical Association of Canada, pp. 239-243.

Vogel, D.C., Vuollo, J.I., Alapieti, T.T. \& James, R.S. 1998: Tectonic, stratigraphic, and geochemical comparisons between ca. 25002440 Ma mafic igneous events in the Canadian and Fennoscandian Shields. Precambrian Research 92, 89-116.

Welin, E., Christiansson, K. \& Nilsson, Ö. 1971: Rb-Sr radiometric ages of extrusive and intrusive rocks in northern Sweden. Sveriges Geologiska Undersökning C666, 1-38.

Welin, E. 1987: The depositional evolution of the Svecofennian supracrustal sequence in Finland and Sweden. Precambrian Research 35, 95-113.

Whitehouse, M.J., Kamber, B.S. \& Moorbath, S. 1999: Age significance of U-Th-Pb zircon data from early Archaean rocks of west Greenland - a reassessment based on combined ion-microprobe and imaging studies. Chemical Geology 160, 201-224.

Whitehouse, M.J. \& Kamber, B.S. 2005: Assigning dates to thin gneissic veins in high-grade metamorphic terranes: A cautinary tale from Akilia, Southwest Greenland. Journal of Petrology 46, 291-318.

Wiedenbeck, M., Allé, P., Corfu, F., Griffin, W.L., Meier, M., Oberli, F., Von Quadt, A., Roddick, J.C. \& Spiegel, W. 1995: Three natural zircon standards for U-Th-Pb.Lu-Hf, trace element and REE analyses. Geostandards Newsletter 19, 1-23.
Witschard, F. 1984: The geological and tectonic evolution of the Precambrian of northern Sweden - a case for basement reactivation? Precambrian Research 23, 273-315.

Witschard, F. 1996: Bedrock map 28K Gällivare, Ai 98-101, 1:50,000, Sveriges geologiska undersökning.

Xie, G. 1982: Petrological characteristics of the Damiao anorthosite complex in Hebei Province, China. Geochemistry 1,369-386.

Zhao, T.-P., Chen, W. \& Zhou, M.-F. 2009: Geochemical and Nd-Hf isotopic constraints on the origin of the $\sim 1.74-\mathrm{Ga}$ Damiao anorthosite complex, North China Craton. Lithos 113, 673-690.

Zwaan, K.B., Fareth, E. \& Grogan, P.W. 1998: Bedrock geological map Tromsø, 1:250,000, Geological Survey of Norway. 